\title{
Technological innovations in the recreational fishing sector: implications for fisheries management and policy
}

\author{
Steven J. Cooke 1 - Paul Venturelli - William M. Twardek • Robert J. Lennox • \\ Jacob W. Brownscombe • Christian Skov • Kieran Hyder • Cory D. Suski • \\ Ben K. Diggles $\cdot$ Robert Arlinghaus $\cdot$ Andy J. Danylchuk
}

Received: 29 July 2020 / Accepted: 2 February 2021 / Published online: 23 February 2021

(C) The Author(s), under exclusive licence to Springer Nature Switzerland AG part of Springer Nature 2021

\begin{abstract}
Technology that is developed for or adopted by the recreational fisheries sector (e.g., anglers and the recreational fishing industry) has led to rapid and dramatic changes in how recreational anglers interact with fisheries resources. From improvements in finding and catching fish to emulating their natural prey and accessing previously inaccessible waters, to anglers sharing their exploits with others, technology is completely changing all aspects of recreational fishing. These innovations would
\end{abstract}

S. J. Cooke $(\bowtie)$. W. M. Twardek · J. W. Brownscombe Fish Ecology and Conservation Physiology Laboratory, Department of Biology and Institute of Environmental and Interdisciplinary Science, Carleton University, 1125 Colonel By Dr., Ottawa, ON K1S 5B6, Canada

e-mail: Steven.Cooke@carleton.ca

P. Venturelli

Department of Biology, Ball State University, Cooper Life Science Building, CL 121, Muncie, IN 47306, USA

R. J. Lennox

LFI, Freshwater Biology, NORCE Norwegian Research Centre, Nygårdsporten 112, 5006 Bergen, Norway

J. W. Brownscombe

Great Lakes Laboratory for Fisheries and Aquatic

Sciences, Fisheries and Oceans Canada, 867 Lakeshore

Rd, Burlington, ON L7S 1A1, Canada superficially be viewed as positive from the perspective of the angler (aside from the financial cost of purchasing some technologies), yet for the fisheries manager and policy maker, technology may create unintended challenges that lead to reactionary or even ill-defined approaches as they attempt to keep up with these changes. The goal of this paper is to consider how innovations in recreational fishing are changing the way that anglers interact with fish, and thus how recreational fisheries management is undertaken. We

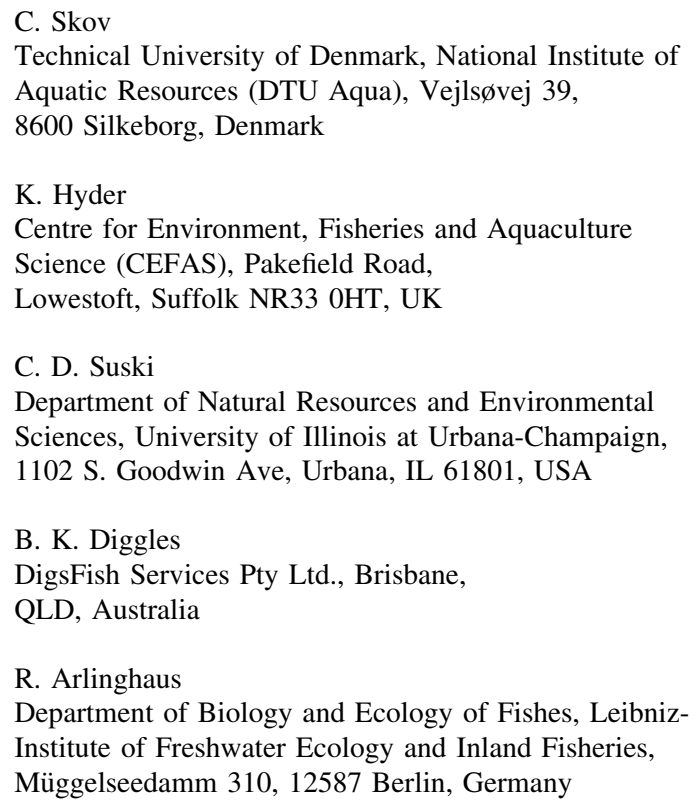


use a combination of structured reviews and expert analyses combined with descriptive case studies to highlight the many ways that technology is influencing recreational fishing practice, and, relatedly, what it means for changing how fisheries and/or these technologies need to be managed-from changes in fish capture, to fish handling, to how anglers share information with each other and with managers. Given that technology is continually evolving, we hope that the examples provided here lead to more and better monitoring of technological innovations and engagement by the management and policy authorities with the recreational fishing sector. Doing so will ensure that management actions related to emerging and evolving recreational fishing technology are more proactive than reactive.

Keywords Recreational fishing - Technology · Innovation $\cdot$ Management $\cdot$ Policy

\section{Introduction}

Throughout the ages, we have witnessed incredible innovations (here we define technological innovation as a new or improved solution to a need or problemoften a product or a process—see https://www. ideaconnection.com/interviews/00218-InnovationOpportunities.html) fueled by human creativity and scientific discovery-from fire to the wheel to penicillin to the supercomputer. The COVID-19 vaccine is just a contemporary example of how human innovations can strongly shape our environment and the wellbeing of human societies. Technology has changed the lives of humans and continues to do so with near daily advances in all realms from entertainment to health care to business to travel to the environment (Roco and Bainbridge 2013). Natural resource management has also had to adapt to changes in technology that have

\section{R. Arlinghaus}

Division of Integrative Fisheries Management, HumboldtUniversität zu Berlin, Invalidenstrasse 42, 10115 Berlin, Germany

\section{A. J. Danylchuk}

Department of Environmental Conservation, University of Massachusetts Amherst, 160 Holdsworth Way, Amherst, MA 01003, USA focused on resource extraction. Often, technology has allowed the more efficient harvest of trees, minerals, and fish - at industrial scales and in increasingly and previously inaccessible water depths (Wils 1998). Key innovations in fisheries include the development of hooks and boats, multifilament nets, echolocation and the diesel engine, to name a few. Fisheries on the high seas are now possible as a result of vessel technology, navigational and echo-sounding equipment, and multiple fishing gear technological innovations (Johnsen 2005; Glass et al. 2007; Tidd et al. 2017), as well as advances in refrigeration technology (Wang and Wang 2005). All of this has substantially changed not only stock assessments (through the impact of novel technology on catch rates overtime), but also the way fisheries are managed. In short, as technological innovations creep into a sector, assessment and management have to adapt (Marchal et al. 2006).

Technology has also influenced non-commercial resource extraction by, for example, hunters and anglers. The muzzle loaders and bows and arrows that were state-of-the-art less than a century ago have been replaced by laser sights, precision scopes, novel munitions, so-called assault-style rifles, and electronic trail cameras. Similarly, what was once a practice involving bamboo rods and simple braided horsehair lines is now characterized by precision-machined reels, ultra-sensitive graphite composite rods, nearly invisible fishing line, battery-powered lures, underwater cameras, and angling apps that allow anglers to share their fishing experiences with others. These innovations in recreational fishing are not unlike those in other "sport" realms (e.g., tennis; Miah 2000a; mountain climbing; Miah 2000b) where innovations have improved the sport, but have also led to some level of controversy (Dyer 2015). Sporting bodies (e.g., the International Olympic Committee) routinely self-regulate by limiting the technology that is permitted in competition, especially as it relates to automation (Rintala 1995). Self-regulation also happens in recreational fishing, where local angling communities may self-constrain the use of certain technologies (e.g., automated boat-based feeding and bait placement in small-scale lake fisheries), either to limit effectiveness, manage conflicts or to navigate the fishery back towards a "fair chase", clearly in light with locally prevailing norms. Beyond self-regulation by norms and local taboos, it is the job of the natural resource manager and policy maker to consider the 
implications of technology on fisheries regulations and policy outside of scenarios where angling clubs or fishing competitions impose rules. However, also the latter players have to continuously adapt to novel technology at local scales.

Innovations in recreational fishing affect how anglers interact with each other and the resource (Devall and Harry 1981). The notion of "fair play", "fair chase", sportsmanship (termed Weidgerechtigkeit in German language, Menzebach and Göllner 2005) and more generally ethics of using different technology to exploit fish has been the subject of several philosophical and popular scientific treatments dating back many centuries (e.g., Walton 2019) and includes to what extent the use of certain gear types and ways of fishing have been considered unethical (e.g., Hummel and Foster 1986; Menzebach and Göllner 2005), such as snagging in some recreational fisheries or using of dynamite or electricity. Also, contemporary code of practices or conducts of recreational fishing provide recommendations to curtail the use of specific practices that are perceived to be particularly damaging and thus unethical (EIFAC 2008; Arlinghaus et al. 2010, FAO 2012). Indeed, innovations in fishing technology have the potential to influence the sustainability of a given fishery, and may thus necessitate a management response (Garcia 1995). In some cases, innovations in fishing technology can benefit fish and fisheries by, for example, creating gears that reduce injury, stress, and mortality of angled fish. Technological innovations that occur at arms length from the fishing industry itself, can also nonetheless change how fisheries operate, or create new risks or opportunities. In modern times, this is exemplified by social media and various smartphone apps that allow anglers to share information with each other and managers (Venturelli et al. 2017). Technology related to recreational fisheries and natural resources can thus be both positive and negative for fisheries management (Pimm et al. 2015) and extends beyond simply increasing capture efficiency. Similarly, there is no requirement that technology and innovation be electronic.

Given the scale of recreational fishing around the globe (particularly developed nations and emerging economies; Arlinghaus and Cooke 2009; FAO 2012; Arlinghaus et al. 2019), there is a need for fisheries managers and policy makers to consider the threats and opportunities that can arise from technological innovation. Although anglers tend to welcome these innovations, technology is a complex issue from a management and policy perspective and may create unintended challenges that require reactionary approaches. On the one hand, anglers are sufficiently numerous that their activities have the potential to have negative impacts on fisheries and aquatic ecosystems (Cooke and Cowx 2004; Lewin et al. 2019; FAO 2012) especially if aided by technology. Anglers seem also to have become more effective in some fisheries in part from advances in technology (Detmer et al. 2020). A recent news article on recreational fishing technology proclaimed that "you would be surprised what is legal in Pennsylvania's fishing waters" (https://www.post-gazette.com/life/ outdoors/2016/09/04/Hooked-on-Technology-You-dbe-surprised-at-what-s-legal-on-Pennsylvania-s-fishingwaters/stories/201609040152), highlighting how ill-prepared fisheries management agencies are for dealing with existing, emerging, and evolving technologies. On the other hand, technological innovation provides an opportunity to work with anglers to promote better management and conservation (Granek et al. 2008), emphasizing that this is a nuanced topic. The goal of this paper is to consider the ways that recreational fishing innovations are changing how anglers interact with fish and thus how recreational fisheries may need to be managed going forward. We use a combination of structured reviews and expert analyses combined with descriptive case studies (drawing on selected examples recognizing there are others) to highlight the many ways that technology is influencing recreational fishing practice and relatedly what it means to changing how fisheries and/or these technologies need to be regulated. Given that technology is ever-evolving, we hope that the examples provided here lead to more monitoring and engagement by the management and policy authorities with the recreational fishing sector. Doing so will ensure that management actions are more proactive than reactive to emerging and evolving recreational fishing technology.

The paper is structured as a review of key technological innovation (Fig. 1) in which the technology and its possible issues are reviewed. We end by providing a synthetic horizon scan on the need to proactively deal with innovations in recreational fisheries. Although our intention was to be inherently global, we acknowledge that most of the examples 


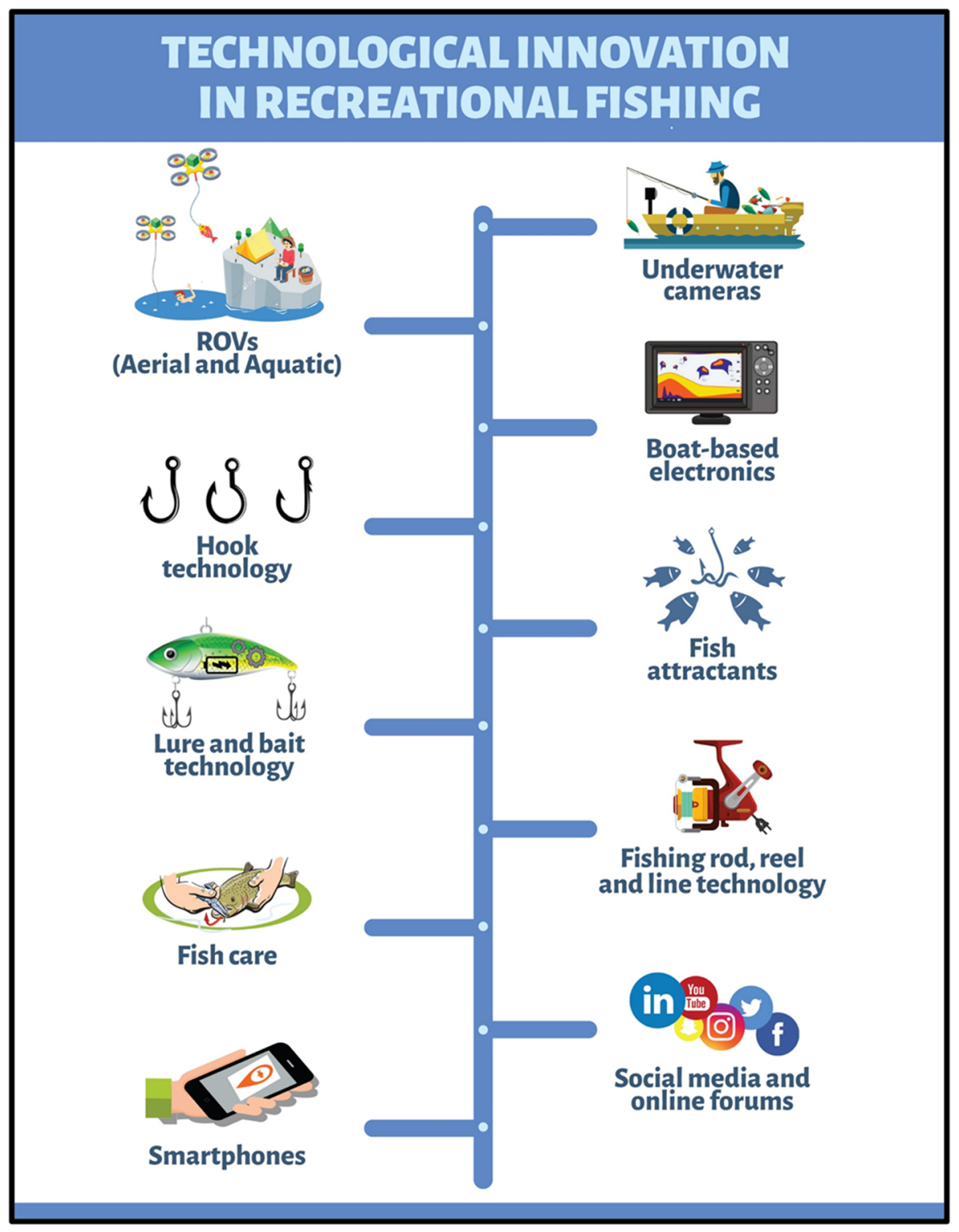

Fig. 1 Overview of the various technological innovations in recreational fishing that we explore in this review

presented here are specific to the developed world where such technologies are readily available and where there are governance structures in place that enable science-based fisheries management (Bower et al. 2020). Nonetheless, online businesses that sell fishing gear enable truly global access to these technological innovations and there is also a substantial angling tourism industry (Ditton et al. 2002) that may bring new technologies to developed countries and use them even if not accessible to or used by residents. We acknowledge that we present several examples of innovations in sequence, not implying any chronological order. Often, selected innovations co-vary and occur jointly. For example, changes in one technology inherently change other technologies (e.g., the advancement of cameras has influenced ROV technology, social media, and smart phones and the way anglers use these technologies). 


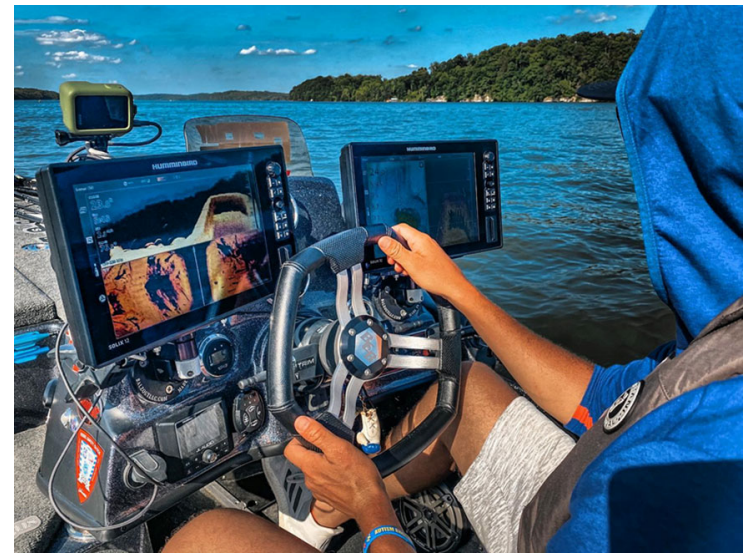

Fig. 2 Extent to which technology is integrated into a modern bass boat. Modern anglers and their electronics function like a cyborg, a connected system of people and machines that can locate and capture fish with increasing efficacy. To illustrate with an example-a black bass angler sits in their boat at the dock in a comfortable chair behind a steering wheel while deciding on fishing locations using digital maps viewed on a $12+$ inch touch screen chartplotter containing detailed information on water depth, habitat type, and known fishing locations that both themselves and other anglers have documented over time. The chartplotter also offers information on environmental conditions including water temperature and barometric pressure, which the knowledgeable angler can use to predict fish habitat and depth use given those conditions. The angler then travels rapidly to a chosen fishing location propelled by a highpowered engine, switching to a bow-mounted electric motor equipped with a sonar transducer and viewing screen (to visualize the underwater environment in front of the boat simultaneously with positioning on detailed maps). The angler sets the GPS-equipped electric motor to automatically and quietly traverse a specific path through the fishing site to minimize disturbance to the fish as the angler approaches (Graham and Cooke 2008). Meanwhile, the angler fishes and is being continuously informed by real time digital images of lake structure and fish locations in 3-dimensions below the boat. Depending on the sophistication of the chartplotter, the angler can be using all this information to digitally map the area and use this information in the future to increase angling efficiency. The above example is one of a technologically advanced and specialized angler, which is not the average. However, increasing affordability of these devices is increasing access to components and versions of that described above. Photo Credit: Carl Jocumsen

\section{Review of technological innovations: application and implications}

\section{Underwater cameras}

\section{The technology and its application}

Underwater tools for observing fish have a long history as aids to fishers across sectors. Single and dual frequency sonar technology are common tools for detecting fish (Horne 2000), but cameras that capture still images and video are increasingly used to gather details about fish size, species, and location that are more challenging to glean using tools that locate fish indirectly. Cameras have become a useful tool for ecological research, with increasing use of camera traps, baited remote underwater video (BRUV), swimby cameras, and videography biologging devices, across a range of applications, from behavioral observations, to estimates of distribution and abundance (Hamel et al. 2013; Struthers et al. 2015; Widmer et al. 2019). Just as scientists benefit from using these remote imaging devices to find and monitor fish, recreational anglers are increasingly using underwater cameras as tools for enhancing the fishing experience.

Cameras used for fishing include those that are directly developed and marketed as tools to enhance fishing productivity as well as the adaptation of general-purpose underwater cameras for observing fish. The popularity of such devices has grown with the increasing availability and reliability of the technology, particularly with respect to adequate miniaturization, image quality, data streaming/storage capacity, and price. Cameras allow anglers to monitor the effectiveness of various fishing techniques, informing potential refinements (depth, bait/lure, retrieval, etc.) to increase catch rates. Ice angling cameras are advertised to anglers seeking better catches by watching their quarry and moving their rig to the correct depth or in an enticing way; these cameras provide an image of the water below, live streamed to a screen above water (e.g., https://www. fisherpants.com/best-ice-fishing-camera/). Line cameras such as the Water Wolf (e.g., https://www. waterwolfhd.com) do not provide such a live feed, but can be attached to the fishing line and set up just in front of the lure so that the angler can later download the footage and inspect tendencies of the fish 


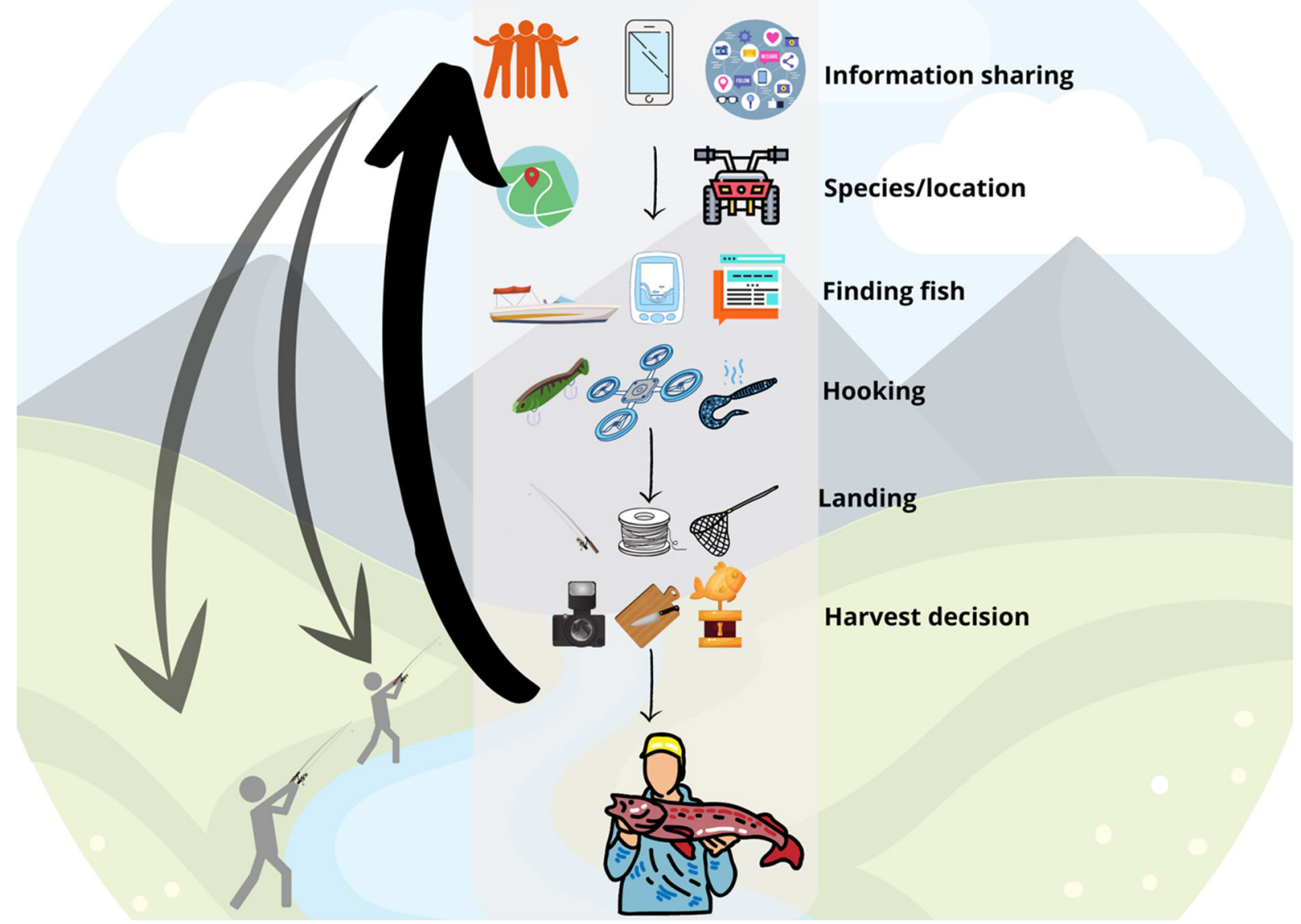

Fig. 3 A tremendous amount of technology is at the disposal of the angling community, with just a small fraction of these tools pictured here. Technology shapes the angling experience, from selecting a fishery, finding fish, enticing and hooking fish,

(Gutowsky et al. 2017). Action cameras such as GoPro Hero cameras can be set up underwater to watch for fish (Struthers et al. 2015), and there are examples of anglers attaching these devices directly to fish to watch their behaviour after release (https://www.youtube. $\mathrm{com} /$ watch? $\mathrm{v}=\mathrm{fUifh} 5 \mathrm{pbZ7Y}$ ) or to watch fish moving into prebaited fishing patches, as is common among specialized common carp (Cyprinus carpio) anglers. Electronic devices such as drones that record and live stream film to anglers are also increasingly important angling tools that are covered in the next section.

\section{Implications for recreational fisheries governance}

Underwater cameras are likely to appeal to the desire of anglers to both catch more fish and better landing fish, harvesting/releasing fish, and sharing information with peers. Social media and other forms of information sharing create a positive feedback loop, whereby more anglers will adopt the technology used by successful anglers

understand their target species. Fish videos can be enjoyable for anglers and, when used effectively, may help to increase angler-fish interactions leading to issues for fisheries managers and the policies that they need to uphold. Fish finding devices are accepted tools, but underwater cameras present a potentially disruptive technology to the fishing landscape because of their high resolution (Struthers et al. 2015). Interestingly, while cameras are often allowed, snorkeling and fishing is often prohibited. These cameras can be used to support conservation/ethics, such as when live streamed footage allows an angler to make a rapid hookset for a fish under direct observation, potentially reducing deep hooking that can occur when a fish or other vertebrate swallows the bait (Twardek et al. 2018; Lennox et al. 2017). However, 


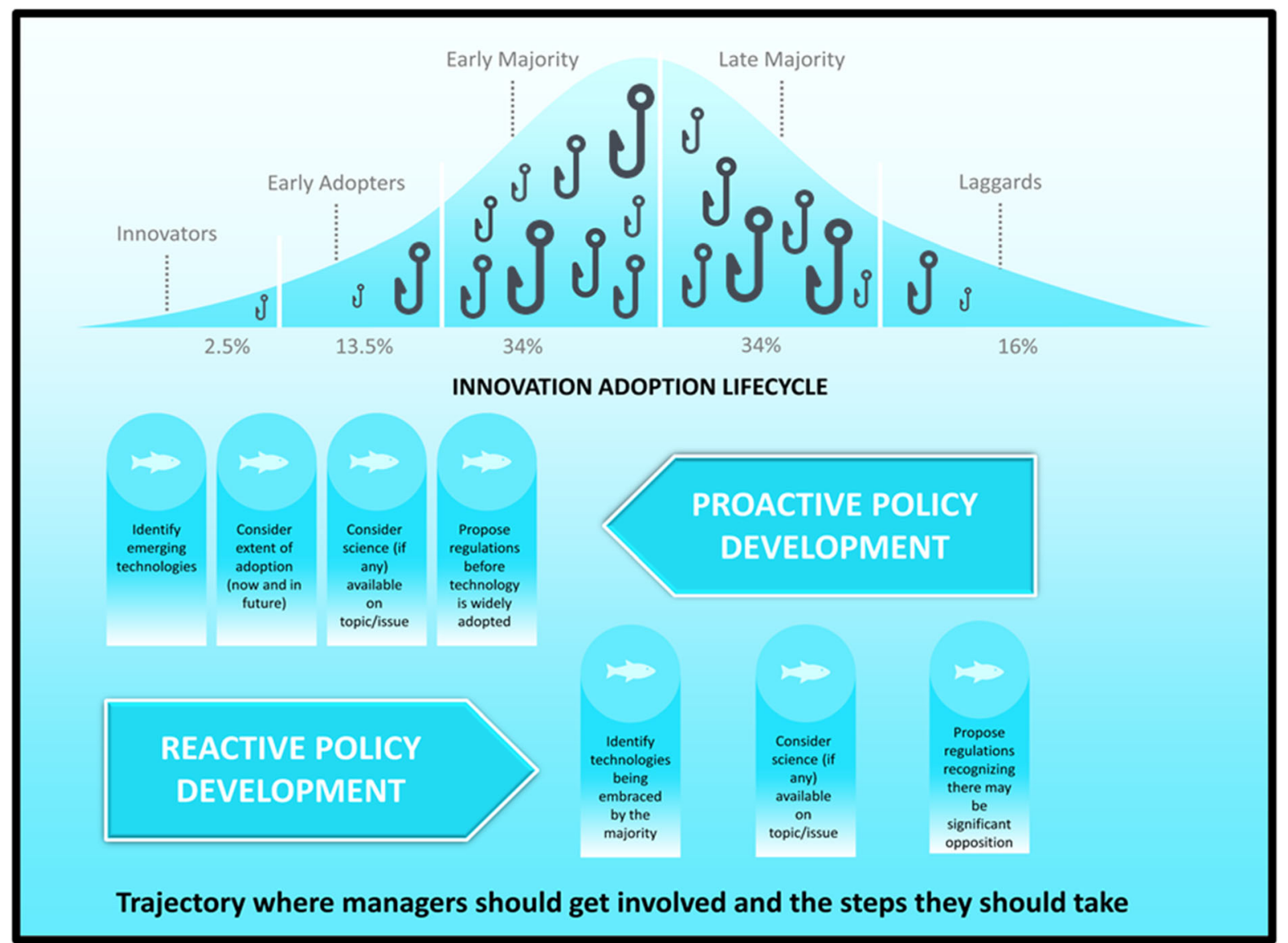

Fig. 4 Visualization of the innovation-adoption lifecycle (adapted from Rogers 1962) along with considerations for alignment with both proactive and reactive management and

video technology can be harmful to fisheries management by increasing catch efficiency and allowing anglers to selectively target fish that they want; this reduces some of the randomness in catching fish (Seekell 2011), enhancing selection towards certain species and size classes if used too effectively unless done knowingly as part of a fisheries management plan.

Fish must encounter the gear to be caught (Lennox et al. 2017). Cameras provide an advantage to anglers by informing them about the position and behavior of fish. Presently available videography tools can add some value to anglers, but are not a panacea for mapping a waterway and finding fish. It is therefore unlikely that cameras will become a crucial component of most tackle boxes, or a tool that greatly enhances fishing success. In some applications, policy development. The trajectory of when managers should become involved and suggested steps for doing so are also visualized

cameras help anglers to learn about fish and it may increase angler effectiveness, but controlled research is needed to determine the extent that cameras are being adopted and if cameras improve fish capture enough to warrant changes to management or policy. Camera technology can be relatively expensive, and therefore its application will likely be limited to specialized and affluent anglers; however, even some cellular phones with cameras are now waterproof, increasing the potential accessibility and utility of this technology. Underwater photos and videos are an attractive alternative to typical catch-and-release photos, which can impact fish through increased air exposure (Danylchuk et al. 2018; see the Smartphone section). The effects of sharing catch photos through social media is discussed in the Social Media and Smartphone sections. Research into how cameras 
affect angler experiences will help managers to determine how important they are to the overall enjoyment of angling, because many anglers may simply enjoy the ability to see fish even if they are not catching more of them. If any policies are needed to address the use of cameras in fisheries, they may need to focus on animal welfare implications of strapping cameras directly to fish (Cooke et al. 2016). Although knowledge is limited on the scale of adoption of present underwater camera technologies by anglers, we feel there is limited risk that cameras will substantially interfere with the health of most fisheries through increasing catches.

ROVs (aerial and aquatic)

\section{The technology and its application}

Remotely operated vehicles (ROVs) have been used for decades in aquatic systems (Yoerger et al. 2007), including for basic exploration, oceanography, archeology, and industrial applications, (e.g., as inspecting oil rigs at sea, Chen et al. 2014; Macreadie et al. 2018). Compared to manned vehicles or use of snorkeling or SCUBA, ROVs can provide access to deep and distant environments without exorbitant equipment costs, complicated logistics of deployment, complex training requirements, and inherent risks to personnel (Perritt and Sprague 2017; Macreadie et al. 2018). These traits, along with the added benefit of real-time image acquisition (versus the use of often dated bathymetric maps and satellite images), make ROVs a practical tool for making observations in and of aquatic systems. Further, in the past 10 years, advancements in the development of small, inexpensive ROVs, especially unmanned aerial vehicles (UAVs), often referred to as drones, has rapidly increased their accessibility and use for science, research, and conservation (reviewed in Floreano and Wood 2015; Macreadie et al. 2018). For under $\$ 1,500$ USD, a small UAV or underwater ROV can be purchased, and have the user flying or navigating the device, as well as capturing real-time digital images and video, within hours of opening the box. This has also rapidly increased the accessibility and use of ROVs within the public domain (Markowitz et al. 2017), prompting personal exploration, creative photography, and recreation notwithstanding the challenges with line of sight and battery life.
The 'domesticating' of drones (Perritt and Sprague 2017) has not gone unnoticed or unappreciated by recreational anglers. The added perspective that can be provided by a small UAV or underwater ROV can shed light on factors such as intricacies in habitat structures and subtle changes in depth, as well as the locations and behaviors of fish. Such real-time reconnaissance and the ability to record and later review high definition digital still images and video can greatly reduce the guesswork that goes into finding fish, and ultimately increase the successful capture of fish by recreational anglers (see also the Underwater Camera section). It has also become a way for recreational anglers to share creative imagery of their fishing adventures on social media.

Recreational anglers have also begun using UAVs to physically assist in the capture of fish. Termed 'drone fishing', a UAV is used to get the terminal tackle to the fish, often well beyond a normal casting distance (Zacharie and Kyuhei 2017). The popularity of this technique started along marine coastlines to access fish beyond surf breaks (https://www.youtube. $\mathrm{com} /$ watch? $\mathrm{v}=8 \mathrm{sdUZqOoAq} 4)$. For this application, the fishing line from a rod and reel is attached to the UAV, the line free-spooled, and the UAV used to place the terminal tackle near the fish that is seen in real-time on a screen associated with the remote control. Overall, this technique is receiving considerable attention on the internet (e.g., https://www. sportfishingmag.com/fishing-with-drones/) and in social media, including reviews of the best drones and features needed to maximize the potential for using UAVs for fishing, such as long battery life and flight stability (e.g., https://www.droneriot.com/bestdrones-for-fishing/). The popularity of drone fishing is likely to increase as UAVs advance (e.g., models that can take off and land from water, or can be operated underwater with remotely operated appendages and no tether). Drones (e.g., remote control boats) are also being used to deliver supplemental feed in some areas, thus "baiting in" fish that can then be captured.

Although technological advancements will aid in its proliferation, drone fishing is not without its controversies within the recreational angling community. Despite being able to provide social good, such as helping disabled people fish (Barillas and Fernandez 2019) and engaging youth with underwater environments (Harmon and Gleason 2009), the broader debate 
includes questions about whether drone fishing provides an unfair advantage to anglers (which would presumably benefit wealthy anglers able to afford such technology), as well as access to fish that normally would be left alone and undisturbed. Independent from the federal and state laws and regulations governing the use of UAVs (covered in the following section), drone fishing is not considered an unethical practice by the International Game Fish Association (IGFA), an international non-governmental organization that promotes responsible, ethical fishing practices. Still, there remains ample discourse within the recreational angling community (e.g. via on-line angler forums) as to whether drone fishing is diluting the pure nature of the activity, or whether the use and impressions of this technology are following the same trajectory as when GPS units became more affordable and accurate to lead anglers to, and back to, productive fishing locations.

\section{Implications for recreational fisheries governance}

The use of ROVs, and particularly the use of UAVs may be restricted due to commercial air space and civil rights laws and regulations (i.e., unwanted or justified surveillance; Tobin 2015; Toonen and Bush 2018). The use of UAVs in many countries is regulated through federal and state laws, with the details varying considerably among jurisdictions. The United States Congress passed a law in 2012 allowing the use of UAVs for hobby or recreational use, similar to what would be expected for the operation of model aircrafts. However, as the popularity and use of UAVs rapidly increased, separate regulations were eventually brought forth by the Federal Aviation Administration (FAA) to reduce grey areas related to the size of drones, the registration of aircraft and display of registration numbers, flying near controlled airspaces and no-fly zones (e.g., near airports, stadiums), required training, and use for commercial purposes (e.g., real estate). This last point is particularly relevant when it comes to recreational angling, especially when a UAV is used by a fishing guide that can potentially benefit financially by putting their clients on fish, making the UAV use commercial and thus requiring additional training, certification, and scrutiny. Many countries also prohibit the use of UAVs in national parks and other public areas, which puts additional restrictions on the use of UAVs for fishing. There are also nuances related to the pilot's citizenship, with some countries (e.g., India) completely banning the use of drones by foreigners. Even in situations where the general laws and regulations at the federal level are relatively lax, states and even communities can implement more specific and restrictive laws over the use of UAVs, all of which need to be taken into consideration as drone fishing gains in popularity. Specific to fishing, both Oregon and Texas have made it unlawful to use drones, including advanced scouting (http://www.eregulations.com/ oregon/19orfw/general-restrictions/, https://tpwd. texas.gov/warden/law-enforcement-faq/drones-uavs). The regulation is broader in California, making it unlawful to use computer-assisted remote fishing, which would, in principle, prohibit the use of any technology to fish (http://www.eregulations.com/ california/fishing/freshwater/fishing-methods-gearrestrictions/). Although we were unable to identify the basis for developing these regulations, they were enacted under fish and wildlife regulations and thus presumably relate specifically to the protection of natural resources.

Where and when drone fishing is permitted, it will be important to determine how this fishing method influences overall catch rates of target and non-target species (i.e., bycatch), as well as the susceptibility of angling-related injuries, especially for fish intended to be released (whether via regulations or voluntary catch-and-release ethic). Given that drone fishing extends the reach of shore-based anglers, there is the potential to target larger fish generally associated with deeper depths or within previously unexploited refuges. This may not only result in the larger fish in a population becoming more vulnerable to target and harvest, but also lead to changes in various aspects of the capture event such that fight times become longer and fish become more susceptible to barotrauma, potentially impacting the physiological stress, injury, and mortality if fish are released (Brownscombe et al. 2017). Depending on the angle of approach to a bait and the extent of the strike, drone fishing could also result in a greater incidence of deep hooking. The same could be said for underwater ROVs, whether making cryptic species more accessible or presenting baits in such a way that increases physical and/or physiological stress. Overall, this relatively new fishing method has not received the same level of scrutiny and evaluation when it comes to its influence 
on individual fish, fish populations, and the necessary guidelines and regulations that make recreational fisheries sustainable.

\section{Boat-based electronics}

\section{The technology and its application}

Modern anglers have access to a suite of technologies that enable them to efficiently navigate amongst and within fishing sites while informed by real time data on the structure of the waterbody, current conditions, water temperature, and location of the fish (Fig. 2). Chartplotters with integrated underwater sonar provide GPS positioning on detailed system maps along with advanced underwater mapping, environmental measurement, and fish-finding capabilities digitized on sometimes large and numerous screens (https:// www.onthewater.com/2019-electronics-guide). GPS also delivers real time updated information such as lunar phase, atmospheric pressure, and tides, which anglers can use to inform their fishing tactics. Boatmounted transducers utilize sonar to generate real time images of fish and structure in up to three dimensions around the boat at ranges exceeding $100 \mathrm{~m}$ (https:// www.saltwatersportsman.com/3D-sonar-for-fishing/). Advances in sonar technology now enable such fine scale details that some fish can be identified to species (https://www.sportfishingmag.com/identify-fish-onsonar/). More advanced users can interpret raw sonar images, but algorithms also provide automatic fish identification and alerts. These details can be used to automatically generate 3-dimensional maps of the waterbody and marked fish locations for later reference (https://insightgenesis.wordpress.com/2014/02/ 14/creating-quality-insight-genesis-maps-from-loggedsonar/). Radar technology can also be used to inform the location of nearby boats (for safety and information on fishing sites), or even birds, which may inform the locations of fish (https://www.marlinmag.com/ how-to-use-radar-for-fishing/). Electric motors at fishing sites enable stealthy and agile maneuvering driven manually using a remote or GPS-guided electric motors that can autonomously maintain position (e.g., over a reef or wreck), or traverse a pre-programed path (e.g., along a weedline), freeing the angler to focus solely on fishing (https://www.fishing. net.nz/fishing-advice/how-to/5-ways-to-fish-with-anelectric-trolling-motor/). We predict that these technologies will also develop rapidly in the near future, particularly in the realms of data processing, utilizing big data sets and artificial intelligence. Massive datasets gathered through connected angler applications are likely to supply machine learning algorithms with the data required to make increasingly advanced recommendations about fishing locations and tactics (which is already happening-see Smartphones section). Sonar data processing will also continue to advance, supplying anglers with increasing information about their environment, while image processing with machine learning models provide advanced information on fish locations, perhaps even specific to species, in real time. Although we focused largely on boat-based electronics, such tools can also be used when ice fishing. Feiner et al. (2020) reported that the majority of ice anglers in Minnesota used sonar units (i.e., flashers) while fishing for panfish and that it appeared to benefit the anglers' harvest. Similar benefits were less apparent for gamefish given that more passive fishing techniques tended to be used (Feiner et al. 2020).

\section{Implications for recreational fisheries governance}

Advances in boat-based electronics are increasing the capacity of recreational anglers to locate, navigate to, and capture fish, which increases the potential for overexploitation of fish populations. For example, some anglers are now targeting individual fish located in pelagic areas with the aid of technology, such that highly selective targeting of individual trophy fish is possible. Therefore, if the fish are released, the likelihood of the individual fish being recaptured multiple times through targeted fishing increases, although no study exists to support this idea. Moreover, through echo-sounding, cryptic aggregations of fish may be effectively found, increasing the likelihood of hyperstable catch rates (Dassow et al. 2020) and generally elevated hooking mortality. However, not all anglers utilize advanced boat-based technologies due to a lack of specialization or financial commitment. Fisheries managers would therefore benefit from knowledge of the frequency at which various technologies and techniques are being used in a given fishery to make accurate assessments of potential exploitation rates, including better assessment of relationships between angler numbers, effort, and exploitation rates. Assessments of the efficacy 
with which anglers can target fish using advanced technologies could be integrated into precautionary approaches to fisheries management through spatial, seasonal, and harvest restrictions. Fisheries managers also often regulate the types of gear allowed in fisheries, commonly restricting the number and types of hooks and rods anglers can utilize, the use of motorized engines, or live bait (Meronek et al. 1995; Sauls and Ayala 2012). Anglers may also implement such measures voluntarily to improve their fisheries (Cooke et al. 2013). Overall, there is potential to extend regulations to include devices such as chartplotters; however, enforcement would likely be complex.

\section{Hook technology}

\section{The technology and its application}

Anglers have used hooks to capture fish for centuries. Early hooks were fashioned from bone or shell, and the use of hooks helped humans access protein and reside in areas that were otherwise resource poor (Thomas et al. 2007; Méry et al. 2008; O'Connor et al. 2011; Fujita et al. 2016). Since their humble beginnings thousands of years ago, innovation with fish hooks has been remarkable (see Fig. 1 in Thomas et al. 2007), and has largely occurred in three areas: shape, piercing/cutting ability, and materials. Collectively, the goal of these modifications has been to maximize capture rates and minimize fish loss, thereby imparting maximum benefits for anglers.

The proliferation of fish hook shapes and designs is vast and impressive. Anglers now have a dizzying array of styles, shapes, and sizes from which to choose. For example, the current Gamakatsu catalog is over 80 pages long (https://www.gamakatsu.com/wp-content/ uploads/2019/03/2019-Gamakatsu-Catalog.pdf), the VMC catalog is over 100 pages (http://www.noscatalogues.net/vmc-fishing-hooks/pdf/emea/2020/? page $=1$ ), and the Mustad catalog is almost 200 pages long. Hooks have also evolved in parallel with different fishing techniques in an effort to facilitate specialized fishing approaches and better integrate the hook with the lure/bait. Recent developments in the area of hooks have included the combination of hooks with weights to provide anglers a sleeker tackle profile that better mimics live prey, while allowing anglers to sink the tackle to desired depths or limit snagging.
Coupled with advances to the overall shape of the hook, have been changes to the location of the hook eye, the orientation of the hook eye (e.g., turned-down or turned-up, varying degree of bends as in https:// www.gamakatsu.com/product-category/freshwater/ jig-hooks-60o/), as well an integration of hooks with swivels or rings to facilitate line attachment and specialized techniques such as drop-shotting. There has also been a proliferation of barb types that include the development of hooks with multiple barbs and outside barbs, all intended to minimize the loss of hooked fish. Several companies also now offer hooks with micro barbs (https://www.gamakatsu.com/product/g-carphump-back/) intended to quickly hook wary fish. On the other hand, hook manufacturers have also developed barbless hooks and many jurisdictions have made these mandatory to reduce capture stress (Schill and Scarpella 1997; Alós et al. 2008). Together, these advances in hook shape and style are intended to facilitate anglers fishing a range of techniques and styles that should appeal to wary fish, or access fish in difficult locations, ideally maximizing capture rate.

A second area of advancement in hook technology relates to developments in sharpness and piercing ability. Hooks uses to be sharpened mechanically, by grinding, filing or wearing away the point, similar to how one would sharpen a knife. Recently, technology has advanced to allow chemical (acid) sharpening, whereby a chemical dissolves part of the hook for a short period of time, thereby allowing a finer, smoother, and sharper hook. Mustad has developed a triangle hook with three flat surfaces that are intended to minimize loss (https://mustad-fishing.com/product/ triangle-hook-4x-hoo?color=Tennese\%20Shad), while Trokar has a similar concept that utilizes a triangleshaped hook that is intended to "penetrate faster and easier" (https://www.eagleclaw.com/about-us/ourbrands/trokar). In addition to specialized cutting/ piercing points, Gamakatsu has developed a Nano Smooth coating that is intended to facilitate piercing (coating for fast penetration).

A final area of technological advancement in hooks relates to the materials that are used in manufacturing. Modern hooks are made by bending (forming) steel wire until it achieves the desired size and shape (https://www.youtube.com/watch?v=NiAkT1bh-9k). Recently, manufacturers have incorporated a number of processes into hook production, such as heat treating (forging) and the use of high-carbon steel that are 
intended to increase strength, reduce brittleness, and prevent bending/breaking under the stress of a fish (Thomas et al. 2007). Hooks made from stainless steel or vanadium designed for marine angling are intended to minimize corrosion, extending the life of a hook and preventing breakage after extended saltwater exposure (https://vmcpeche.com/vmc-coatings). Manufacturers have also worked to develop non-reflective, low-visibility hooks (https://mustad-fishing.com/product/ triangle-hook-4x-hoo?color=Tennese\%20Shad) to minimize the likelihood of detection.

Hooks are designed to injure fish by piercing their flesh. As such, a great deal of effort has been invested in minimizing the possibility of injuries for angled fish and facilitate intentional release, thereby resulting in improved conservation benefits. Circle hooks are a prime example of development in hook technology with conservation benefits, because circle hooks have been shown to hook fish in injurious locations less often than conventional J-style hooks, thereby improving outcomes for released fish and reducing mortality (Cooke and Suski 2004). Owing to this conservation value, virtually all hook manufacturers now offer a wide array of circle hook options to anglers. Many companies are also actively promoting the conservation benefits. Mustad, for example, highlights circle hooks as a way to "Avoid deeply hooked fish and give it a real chance at swimming back out into the water" (https://mustad-fishing.com/products/circle-hooks). In addition to circle hooks, Gamakatsu currently offers a line of 'Magic Eye' hooks that are "far kinder to our finned friends" because they facilitate release of hooked fish (https://www.gamakatsu.com/product/ magic-eye-tuna-plug-3x/).

It is difficult to predict future changes or improvements to hook technology because companies are inclined to protect proprietary information. However, an informal survey of patents on Google Scholar revealed continued innovation related to reductions in the loss of fish, and increased capture efficiency. For example, a recent patent outlined the use of dual barbs on a fish hook "making it more difficult to dislodge the hook while recovering a hooked fish" (Lee 2017); another described a hook with multiple barbs that results in "increased and more secure hookups" (Winter 2017). Patents also exist for integrating attractants into fish hooks, intended to attract fish and increase capture rates (Wang 2016) (See the Fish attractants section), as well as for the use of fluorocarbon hooks that are transparent or translucent but strong (Lorimer and Ray 2016). In addition to efforts that are intended to increase capture rates, work is also underway to have hooks minimize negative effects on captured fish including making hooks less corrosion-resistant when ingested and re-designing barbless hooks to improve safety (Yepez and Guevara 2017), and to integrate antimicrobial coatings and/or an anti-inflammatory coating to minimize infection, treat the puncture wound, and minimize nociception for captured fish (Hopkins 2017). Novel hook mounts have also been created to increase hook exposure and ultimately capture rates (Bursell and Arlinghaus 2018). In addition to hooks, there have been innovations in bait clips that allow anglers to cast the sinker out and then clip a large bait on to the line and slide it out which has enabled anglers to access fish (e.g., Lichia amia) that were previously inaccessible (Maggs et al. 2016).

\section{Implications for recreational fisheries governance}

When examined as a whole, recent and potential changes to hook technology, are heavily skewed towards increasing capture rates and minimizing the loss of hooked fish. This may have policy and management implications if anglers are sufficiently effective as to maintain elevated catch rates despite reduced population sizes, or if previously invulnerable species/size classes of fish become targets for anglers. Managers should therefore be aware of how fish hook technology could impact fish populations through increased capture. There is certainly opportunity for fisheries managers to work more closely with hook manufacturers in an attempt to develop "solutions" that work for specific fishing scenarios or issues. It is common for angling regulations to specify the number and types (e.g., single, treble) of hooks that an angler can use on a line, and whether barbs are allowed, but to omit finer details related to the hook design (e.g. colour, material, number of barbs). Definitions can sometimes be an issue. For example, when the Atlantic States Marine Fisheries Council decided to require circle hooks for striped bass, they had to first define "circle hook" so that there was an enforceable regulation. In the end, they opted to simply identify specific makes and models of hooks that were considered to be circle hooks when unmodified. Fisheries managers should also pay close attention to 
hook types that may increase hooking and landing rate, but do so with a cost to the fish in terms of greater injury or longer handling times (e.g., multi-barb hooks could potentially represent such an example).

Fish attractants

\section{The technology and its application}

Attempts by recreational fishers to utilise scents to stimulate the well-developed olfactory (smell) and gustatory (taste) organs of fish to increase their catch rates are probably as old as recreational fishing itself. Subsistence fishers used natural organic bait for thousands of years to attract and catch fish, so the commercial development of scent products early in the development of the recreational fishing industry (e.g. Fish Lure Corp. 1954) was expected. However, modern scientific understanding of fish physiology and nutrition has provided precise insights into the roles of the various chemical compounds that are associated with attractive and repellent behaviours in feeding fish (Loeb 1960; Mackie 1982; Carr and Derby 1986; Hara 1994; Kasumyan and Doving 2003; Kasumyan 2019). This research has found that fish respond to various water-soluble substances including amino acids and their derivatives, small peptides, amines, nucleotides, inorganic salts, sugars, carboxylic, and bile acids. This body of research also found that the effective combinations of palatable, aversive, and ineffective compounds often differed markedly among fish species (Carr and Derby 1986; Hara 1994; Kasumyan and Doving 2003; Kasumyan 2019).

Research into fish chemoreception was largely unexploited by the recreational fishing tackle industry until the mid-1980s. Nearly all of the so called "fish scents" on the market in the 1980s were based on various fish oil formulas, which were insoluble in water and thus incompatible with the olfactory and gustatory organs of fish (Carr and Derby 1986; Hara 1994; Kasumyan and Doving 2003). These products thus acted mainly as masking agents designed more to "attract fishermen rather than fish" (Field and Stream 1986), and their poor attraction performance led to widespread scepticism amongst anglers in relation to the effectiveness of fish attractants. But no scientific study is available to back these claims. Relatedly, in the carp angling industry alcohol-based flavours proliferated during the same time, carrying immense variation in smell and tastes to be added to paste-based baits for non-piscivorous fish. Again, no scientific study on the relative performance of flavoured and unflavoured baits exists. A more scientifically rigorous approach to the development of fish attractants emerged in the mid-1980s as scientists began working with fishing tackle companies such as Berkley (see Jones 1989, 1990) to develop synthetic products such as Strike attractant spray and Power Bait poly vinyl chloride (PVC) soft plastic lures that contained scientifically proven water soluble fish attractant compounds. The commercial availability of these products finally allowed anglers to reduce reliance on fish oils (http://www.berkley-fishing.com/Berkley-aefish-attractants-leave-the-oil-at-home.html), but may have led to other problems including ingestion of damaged or discarded scented soft plastic lures by wild fishes (Danner et al. 2009).

Acknowledging the potential pollution and fish health issues associated with the loss of plastic lures into the aquatic environment, research in the recreational fishing industry continued to evolve in the early twenty-first century with development of various artificial soft baits from biodegradable materials, which can exude attractants into the water at much higher rates (up to 400x) than traditional PVC soft lures, thus approaching or even exceeding the attractant concentrations exuded by natural baits. Such products included Berkley Gulp, Food Source, Atomic Guzzlers, and Rapala Slam baits (Schultz 2004; Merwin 2007; Savvas 2009). Since the introduction of these scientifically formulated fish attractant products, their effectiveness for attracting fish has become more readily accepted by recreational anglers, who are now able to compare their performance against the traditional fish oil derived products (Savvas 2009) (https://blog.fishingtackleshop.com.au/fish-attractantscents/). Nevertheless, a laboratory study of the effectiveness of 21 commercially available fishing scents conducted in 2007 utilising a range of Australian fish species (Acanthopagrus australis, Chrysophrys auratus, Lates calcarifer and Macquaria novemaculeata) found that 19 out of the 21 products did not significantly influence the behaviour of the experimental fish, or were mild repellents and hence were ineffective (BK Diggles, unpublished data). Because much of the work on fish attractants is 
proprietary, there is little available "open" science on this topic.

\section{Implications for recreational fisheries governance}

The main management and policy implications of this technology relate to the potential for increased fishing efficiency and post-release mortality due to hooking damage caused by fish ingesting scented lures and baits deeper than if they were caught using unscented lures or bait. The former concern has already led the state of Minnesota to ban the use of "bait cloud" fish attractants and similar products that are intended to attract fish and enable capture (see https://www.dnr. state.mn.us/regulations/fishing/baitcloud.html). The latter concern may result in bans on the use of scented lures in certain areas or jurisdictions. For example, Schisler and Bergersen (1996) found that rainbow trout (Oncorhynchus mykiss) had between 5.5 and 8.2 times higher hooking mortality rates when caught using scented artificial baits (Power Bait) that were fished actively or passively, respectively, compared to artificial flies. This study led to bans on the use of scented artificial baits or any chemical attractants in some "lure only" management jurisdictions (e.g., in some National Parks in Canada; See https://laws-lois. justice.gc.ca/eng/regulations/C.R.C.,_c._1120/Full Text.html).

In contrast, Dunmall et al. (2001) studied the hooking locations and post-release mortality of smallmouth bass (Micropterus dolomieu) that were caught using minnows, nonscented plastic grubs, or grubs scented with chemical attractants (salt, Power Bait (scented PVC lure), or oil of anise). They recorded 0\% mortality and found that the type of bait used to capture the fish had no significant effect on the depth of hook penetration or the anatomical hooking location. However, fish attractants can be highly speciesspecific, and while oil based attractant products are unlikely to influence the gustatory behaviour of fish, the PVC Power Bait type lures studied by Dunmall et al. (2001) have been surpassed by the more recent biodegradable lure technology that has been advertised as having upwards of $400 \times$ more scent dispersion (Berkley/Pure Fishing data). Hence the results of Dunmall et al. (2001) may not reflect the current reality, and indeed the deep hooking frequencies for today's scented lures may be similar to those usually observed using organic bait for certain fish species (Diggles et al. 2020).

There is also the possibility that the use of effective fish attractants will increase the frequency of ingestion of discarded or lost scented lures by wild fish, which may result in reduced growth rates or other adverse health effects if the ingested lures are not digestible or biodegradable (Danner et al. 2009; Raison et al. 2014) and cannot be passed through the digestive tract (Sanft et al. 2018). Even still, lures made from biodegradable materials may persist virtually unchanged for at least two years underwater (Raison et al. 2014). At least some of this slow degradation is likely to be due to the reduced oxygen availability underwater compared to the normal biodegradation standards applied to materials composted on land (BK Diggles, unpublished data). However, again, the results of any such studies are likely to be specific to the fish species, lure material, and attractant products examined. Furthermore, the use of scented artificial baits provides several advantages for managers, not the least being the elimination of bait bucket transfer (Ludwig and Leitch 1996) and the many significant biosecurity and pest translocation risks associated with use of organic baits (Diggles 2011; Scott-Orr et al. 2017), as well as the reduction of harvesting pressure on natural bait species. For these reasons, it is impossible to arrive at any general conclusions on the management and policy implications arising from increased use of effective fish scents by recreational anglers at this point in time, except to anticipate that research to develop improved artificial baits and fish attractants is likely to continue.

Lure and bait technology

\section{The technology and its application}

Fishing tackle manufacturers have long attempted to create artificial lures or enhance organic baits that attract the attention of both fish and the angling consumer. Dr. Loren Hill's Color-C-Lector from the early 1980s was one of the first attempts to introduce science and technology into lure manufacturing. This handheld device used water clarity relative to ambient light and depth (and eventually $\mathrm{pH}$ ) to recommend colors that would be most visible to fish. Several lure manufacturers aligned their own lure color options with those recommended by the Color-C-Lector. At 
about the same time, the Banjo Minnow (see https:// www.asseenontvvideo.com/511810/Banjo-006-Minnow -Fishing-Lure.html), a soft plastic lure, was being marketed aggressively (e.g., "as seen on TV") using phrases like "the most lifelike fishing lure ever created" and "it triggers a genetic response and compels fish to bite even if they are not hungry". There were also attempts to incorporate "guanine" (a biological compound that occurs in fish scales) into lure paint in what became known as the "G-finish". These early attempts paved the way for other innovations that may be relevant to managers. For example, some lures also use a "photo" finishing process where actual images from baitfish are incorporated into lure finishes rather than simple painting. In addition, a number of new lures have incorporated battery-powered LED lights that illuminate the lure or flash for use at depth or at night or have used UV sensitive materials that are supposed to be sensed by fish better at depth or with certain illumination. Similarly, many lures also incorporate glow-in-the-dark paint, although they require exposure to light in order to "charge". There have also been recent developments with "robotic" lures (e.g., https://roboticlure.com/) that features action that is apparently enticing to fish. Some lures even use solar-powered micro-electronics to vibrate (https://biteemsolarlures.com/). There have also been recent innovations in devices that are inserted into dead bait (e.g., a dead baitfish) to make it move (https://www.kickstarter.com/projects/1029637745/ zombait-a-robotic-lure-that-brings-dead-fish-back). Noise has been a common aspect of lure design using rattles or clackers. However, use of electronics has created new opportunities for manufacturers to incorporate realistic (potentially playbacks) sounds from baitfish to potentially improve capture of target fish (see electronic baitfish sound system from Livingston Lures; https://www.livingstonlures.com/learn/ our-technology). There have been attempts to incorporate "fish attracting voltage" (also termed "voltage tuned") into lures (e.g.; https://www.lurecharge.com/ intro-products; https://www.youtube.com/watch?v= nEKaHcy36Is) but this is a reasonably new phenomenon and we are unaware of any published research on its efficacy or effects on fish.

Organic bait innovations have also occurred with a focus on better preservation of baitfish and crustaceans. Although initial efforts were driven largely by the bait industry and their interest in creating opportunities to preserve bait for shipping and sales without the complexity of keeping bait alive, more recently such work has been sponsored by governments in an attempt to overcome biosecurity issues related to accidental or intentional release of live bait. For example, the natural resource management agency in Quebec banned use of live bait fish by recreational anglers in 2017 and prefaced that action with research focused on demonstrating how bait fish could be best preserved to enable the storage and use of dead bait fish (https://www.quebec.ca/en/tourism-and-recreation/ sporting-and-outdoor-activities/fishing-rules/fishingtechniques/). While preservation of artificial baits can be much longer than for organic baits, some of the storage solutions can be toxic to fish (Rapp et al. 2008). In Wisconsin, the Department of Natural Resources has shared information (see https://dnr. wisconsin.gov/sites/default/files/topic/Fishing/VHS_ vhs_sellingfrozenbait.pdf and https://dnr.wisconsin. gov/topic/Fishing/vhs/vhs_preservation.html) on preservation methods for organic baits that reduce likelihood of spreading the disease Viral Hemorrhagic Septicemia via bait fish given that freezing alone is insufficient to kill that virus.

\section{Implications for recreational fisheries governance}

Lure and bait innovations involving electronics or mechanics that generate light, noise, or movement are most likely to be of interest to fisheries management and policy. Use of lights for night fishing is often restricted in recreational fisheries, so extending that to include lighted lures could be relevant in some contexts. Similarly, the use of enhanced lures (or devices that cause dead bait to move) may be deemed to give the angler an unfair advantage to the point where the activity is no longer consistent with the spirit of recreational fishing. Ultimately, this is only an issue if it leads to improvements in catch (and harvest) or contributes indirectly to fishing mortality via hooking mortality, for which there is no scientific study. For example, if lures that include light, noise, electricity, or mechanical aspects are indeed more realistic then they could be more deeply ingested by fish, possibly creating problems in catch-and-release fisheries. We are unaware of any jurisdictions with regulations that restrict such lures at present. In Minnesota, any batteries contained in lures must not contain mercury (https://www.revisor.mn.gov/ 
statutes/cite/97C.335). In catch-and-release fishing more "flashy" and "noisy" lures, will lead to faster hook avoidance learning will be achieved, such that some of the gear innovations might quickly loose their catch potential. Moreover, in some instances there may be benefits to limiting the use of certain tactics. For example, lures that behave like live bait-or the use of devices that make live bait move and seem alive even when dead-could be effective replacements for live bait that may be regulated because of issues with biosecurity, fish introductions, or endangered species. The use of lures with "fish attracting voltage" is potentially problematic in that there may be sublethal physiological consequences for fish that are to be released. In most jurisdictions, the use of "electricity" for fishing (i.e., electrofishing) is restricted to fisheries scientists and assessment biologists (e.g., in Mississippi; https://www.mdwfp.com/law-enforcement/ fishing-rules-regs/- yet there is no mention of electrified lures) so it may be reasonable to consider extending to specify lures that emit electricity if deemed necessary. That said, the level of electricity generated by these devices is presumably quite low and therefore may not be an issue. Innovations in bait fish preservation are generally deemed to be beneficial and provide fisheries managers with new tools for limiting spread of non-native bait as well as diseases they may carry.

Fishing rod, reel and line technology

\section{The technology and its application}

Fishing rod technology has focused largely on making rods that are lighter and more sensitive (e.g., with IM8 graphite) than early (e.g., bamboo, fibreglass, and boron models) or less expensive rods while also retaining or increasing strength and reaction characteristics. Recently, the first Bluetooth-enabled fishing rod was released, which allows anglers to immediately record aspects of their catches through a linked app (see: https://www.outdoorhub.com/news/2019/07/22/ abu-garcias-virtual-rod-first-ever-bluetooth-enabledfishing-rod/; note-this is most relevant to the smartphone section so is discussed below). Reels have also become much lighter, with an emphasis on mechanics that enable long-distance casts, more efficient line retrieval and better drag systems. Some baitcasting reels now include a digital micro-controller that allows the angler to cast into the wind without issue. There have also been developments in some level-wind reels that retrieve line and reel in a fish with the push of a button-typically employed in deepwater environments. Some reels also have an automated jigging feature to make lures/bait look lively (https://www. sportfishingmag.com/techniques/rigs-and-tips/powerplay/). In fly fishing, technology has allowed for the advance of stronger, more efficient drag systems (e.g., carbon), that improve the ability of anglers to land fish, even those of considerable size (e.g., large sharks, Atlantic tarpon [Megalops atlanticus], Atlantic bluefin tuna [Thunnus thynnus]).

Fishing line is another important aspect of the rod and reel setup. New lines are often thinner yet stronger than those of yesteryear (https://www.in-fisherman. com/editorial/trends-in-fishing-line/154077). Early fishing lines were made of braided natural materials (e.g., horsehair, cotton) that were replaced largely by monofilament nylon until innovations in braided line technology brought that line back to the fore in the 1990s. The new generation of braided "super" lines (gel-spun, hollow core) bring strength (including resistance to abrasion) while doing so with smaller diameter. These lines also provide more sensitivity and reduce stretch such that it is possible to fish with more line out (e.g., deeper or further) while still being able to feel the bite. Traditional monofilaments made from nylon are now competing with fluorocarbon lines that claim to be nearly invisible to fish. The same is true for fly fishing lines, with advanced materials and fly line tapers being developed and used to improve casting, increase sensitivity, and reduce the ability for fish to see the line. Some manufactures are also taking a technological approach to make more environmentally friendly fly lines, rather than relying on PVC and other materials that weather through the production process or when loss in a lake or stream can have hazardous effects on biota.

This collective suite of rod, reel, and line innovations provides the angler with a number of advantages over gear from the past-mostly by allowing the angler to become less fatigued while accessing or covering more water and doing so with lines that are tougher, less visible, and more sensitive. There have also been innovations in fishing "systems" - how rod, reel, and line are deployed. For example, ice fishing devices that automatically set the hook for the angler (https://mailtribune.com/lifestyle/ice-fishing- 
invention-hooks-anglers) and downriggers and kites that adjust depth automatically through links to smartphone apps and boat electronics (e.g., GPS and depth finder).

\section{Implications for recreational fisheries governance}

At present, the most important message for the manager and policy maker is that innovations in rod, reel, and line technology can provide anglers with access to waters that were previously not "fishable" (especially very deep water). As such, there may be need for new recreational fishing regulations for species that had previously been deemed to not be at risk as a result of recreational fisheries interactions. Additionally, anglers may have higher effort and total catches if innovations reduce fatigue. Other issues related to rod, reel, and line choice are somewhat challenging to consider in terms of regulatory options. The exception would be the automation of reels or other devices that assist with getting a lure/bait to depth, or making it move in a certain way (including the hook set). These tools already exist (e.g., electric reels) and are used in some specialized fisheries. For example, California forbids the use of winches while angling, but permits the use of electric reels (http:// www.eregulations.com/california/fishing/saltwater/ finfish-fishing-gear/). Alaska and New South Wales Australia failed to prohibit power-assisted reels (https://www.ktoo.org/2012/02/28/fisheries-boardkeeps-powered-reels-legal/; http://www.fishingworld. com.au/news/fw-comment-shame-acorf-shame)

whereas such gear is restricted (except for exemption for disabled anglers) in Canada for anglers who target halibut in Pacific waters (https://www.sportfishingbc. com/forum/index.php?threads/electric-fishing-reels. 34872/).

\section{Fish care}

\section{The technology and its application}

There has been a recent push to improve the welfare of fish that are captured-and-released by anglers (Danylchuk et al. 2018) as recognition grows that handling practices can influence the physiological stress and survival of released fish (Brownscombe et al. 2017). This includes a wide array of devices used to land, unhook, and promote recovery of captured fish. Tools such as pliers have conventionally been used to unhook fish, but more recent innovations include lip gripping devices (used to secure a fish by the lip while taking out the hook) and dehooking devices that allow fish to be released without being touched by the angler or removed from the water (see many patents filed for dehooking devices; Harrison 2004; Baiamonte and Wegner 2010; McFann and McFann 2010). Recent advancements in lip gripping devices also include products to help to handle large fish (e.g., tuna) that are landed from boats with high freeboard, which could potentially help with fish recovery and release (e.g., Seanox Big Game Pliers, https://www.pechextreme. com/en/other-pliers/3062-seanox-big-game-pliers-fortuna-3541100765040.html). Lip gripping devices have become common, but their use remains controversial for some species given that there is evidence of high rates of mouth injury associated with their use (Danylchuk et al. 2008; Gould and Grace 2009). Net technologies have developed greatly from knotted nylon nets to the rubberized, knotless nets that minimize epithelial damage during landing compared to other landing net materials (Colotelo and Cooke 2011). Unhooking mats have been designed for hook removal of common carp with many different varieties available including ones that are padded and include inflatable edges. Various technologies have also been designed to retain landed fish in water (e.g. fish cradles, recovery bags, live wells) while anglers prepare measurement tools or cameras. Fish cradles result in fish retention directly in the water body, whereas live wells store fish on a boat, with surrounding water pumped or spilled directly into the well. Live wells are often used for longer holding periods associated with angling tournaments but could also be used in the case of high grading when there are bag limits or slot limits. Although the premise of a live well is to keep fish alive, survival can be compromised when they are not operated properly and create hypoxic conditions (Keretz et al. 2018). Recent innovations include the use of padding to reduce injury of fish during transport (Brooke and Tufts 2012). There are also chemical live well additives marketed to anglers to improve the recovery of fish following capture (i.e., sedating catch, replacing the slime coat, healing wounds, and reducing weight loss). Scientific evaluations of these products are limited, and have not reached a consensus on whether they are beneficial or detrimental (Cooke et al. 2002; Gilliland 2003; Ostrand et al. 2011). There 
have also been attempts to develop analgesics that can be applied to areas of the fish where the hook penetrated in an attempt to address nociception issues (e.g., Catch and Relieve spray) or disinfect the fish (e.g., often used by European anglers targeting carp), but it is unclear if these products have any benefit or if they introduce chemical residues in fish that endanger the public.

In many cases, innovations have been designed to improve the ease of fish handling, but may not reduce harm to the fish itself. Fish handling gloves are designed to get a firm grip on slimy fish and to prevent cuts and punctures to the angler, though there have been few studies evaluating the impacts to the slime layer across species' and glove types (but see Murchie et al. 2009). And in European carp angling, anglers are using so called unhooking mats to keep the fish under water and avoid mucus abrasion during dehooking and the making of memorable pictures. Various recovery tools exist to try and increase the survival of captured fish. As previously mentioned, recovery bags can be used to hold fish prior to release, allowing fish to recover reflex ability, reduce behavioural impairment, and lower predation risk (Brownscombe et al. 2013). Trophy carp anglers often use de-hooking mats for hook removal (Rapp et al. 2014). Fish may experience barotrauma when angled (particularly when brought up quickly from depth), leading to organ damage (Rogers et al. 2008) and an inability to return to depth upon release. Devices to 'vent', 'fizz' (i.e. puncture the swim bladder to release expanded gases), or rapidly recompress fish are available to return fish to neutral buoyancy. A review on the efficacy of venting on captured fishes indicated that this strategy is generally not beneficial (Wilde 2009), though there is evidence that it can be beneficial for some species (Drumhiller et al. 2014). Fish recompression works by lowering fish back to appropriate depths with descending devices (e.g. weighted lines and inverted hooks or weighted baskets with open bottoms), allowing swim bladder gases to recompress. Descending devices (e.g. https://seaqualizer.com/product/seaqualizer-

descending-device/) have proven highly effective across species (Butcher et al. 2012; Drumhiller et al. 2014; Bellquist et al. 2019) and avoid the potential of damaging organs during the venting process (discussed in Wilde 2009). Other recovery measures used by anglers include the pouring of carbonated beverages (e.g. Mountain Dew) on actively bleeding gill arches. This recovery measure is based on the untested hypothesis that the acidity of these beverages can cauterize the wound and stop bleeding, though the potential for this acidity to damage sensitive gill tissue is equally likely (https://theoutdoorforum.net/index. php/2017/10/05/the-fishing-line-stop-pouring-soda-onfish-gills/). This technique is not being promoted by the carbonated beverage industry; rather individual anglers and some media outlets have caused it to go viral prior to it being validated.

\section{Implications for recreational fisheries governance}

There is strong potential for fish care technologies to benefit the welfare of fish that are intended for release (because of mandated regulations or voluntary actions), though the opposite is possible if technology is improperly incorporated into the recreational fisheries management toolbox. Many of the technologies that are available to improve fish care have yet to be formally evaluated, limiting the ability of fisheries managers to make evidence-based decisions on their implementation or prohibition in recreational fisheries. The value of these technologies is also likely to be context- and species-specific (Cooke and Suski 2005; Raby et al. 2015), so it can be difficult or even inappropriate to apply findings from one setting to another. When available, managers should rely on evaluations that most closely mimic the fishery in question (i.e., species, methods, gear, environmental conditions). A review of management agency websites indicated that it is common for unevaluated or contentious practices/technologies to be recommended to anglers by natural resource agencies (Pelletier et al. 2007). In the absence of reliable information, it may be advisable for managers to implement a precautionary approach and prohibit technologies until their efficacy can be evaluated, without creating barriers to fishery access (Hilborn et al. 2001). Nonetheless, there are many fish care regulations that managers could implement (and have implemented) that would undoubtedly benefit released fish across contexts, including the mandatory use of pliers or dehooking devices, knotless rubber nets, and descending devices where barotrauma is common. For example, dehooking devices (e.g. pliers) are required when angling for reef fish (e.g. snapper, grouper) in State Waters of the Gulf of Mexico and the Atlantic (Florida Fish and Wildlife Conservation 
Commission). Descending devices are a requirement under British Columbia's 2019-2020 Tidal Waters Sport Fishing Licences to increase the post-release survival of decompressed rockfish (Fisheries and Oceans Canada 2019). In some cases, the technology itself could benefit fish, but only if used correctly. As such, education efforts at improving angler awareness alongside or instead of regulations may be critical. A great example is the inclusion of compressed oxygen in modern bass boat live wells. When used to keep oxygen at $100 \%$ saturation it can be beneficial but supersaturation is possible which can have negative consequences for bass in live wells (Suski et al. 2006). One area that requires careful monitoring by regulatory agencies is the chemicals that fish are exposed to during live well retention or for "pain management". Such substances might be harmful to humans if they enter the human food system-an issue that likely extends beyond natural resource management agencies to include public health and food safety organizations (e.g., US FDA, Canada Food Inspection Agency, Health Canada).

\section{Social media and online forums}

\section{The technology and its application}

The popularity of social media accelerated in the first decade of the new millennium. This came as a response to the World Wide Web evolving from a platform hosting mainly static information to one that includes a great deal of user generated content, which is considered the lifeblood of social media (Obar and Wildman 2015). Most social media platforms allow users to create a profile that connects to a website or an app that is maintained by a social media service, e.g. Facebook, Twitter, Snapchat, Instagram, or WhatsApp. User profiles can be considered the backbone of social media because they enable social network connections between user accounts (Obar and Wildman 2015). Social media has become wide spread within a short period (e.g. $69 \%$ of the US population used Facebook in 2019 (https://www.pewresearch.org/ fact-tank/2019/04/10/share-of-u-s-adults-using-socialmedia-including-facebook-is-mostly-unchanged-since2018/), and has significantly changed the ways that humans interact. Clearly, social media has also affected the way that anglers interact; today, thousands of social networks share angling related information by the minute. This includes practical angling information (where to fish, what fish species, etc.) as well as political/opinion information when social media is used to promote and debate governance, regulations, policies, pollution, ethics, and codes of conduct. The rapid use and development of social media in recreational fisheries clearly provide a huge source of information both for anglers and researchers (Monkman et al. 2018a). This knowledge can be harvested by so-called net scraping technologies that use code to search homepages and online forums for specific content. The data can then be applied in culturomics studies to understand trends in resource use patterns and user attitudes (Jarić et al. 2020; Sbragaglia et al. 2020).

\section{Implications for recreational fisheries governance}

The emergence of social media has provided anglers with easy access to a large flow of information from peer anglers about all aspects of recreational fisheries, e.g. where to fish and what gear to use. In addition, researchers and managers increasingly share research and management information through social media, which therefore also becomes easy to access by the angler. When the information shared with the angler is true and correct, the anglers may increase their knowledge. In time, such a knowledge boost among and within anglers is likely to increase angler empowerment, i.e. qualify them to challenge and influence the management of their fisheries. This can lead to new and more dynamic and interactive comanagement regimes, where information is swiftly shared among managers, researchers and anglers, and where anglers are more involved in decision making and management (Arlinghaus et al. 2019). This will likely increase the transparency of management decisions, increasing trust from anglers. However, misinformation on social media platforms can have negative implications for recreational fisheries management. For instance, it has been widely circulated by anglers that pouring carbonated beverages on injured fish will help reduce injury and increase survival despite no empirical evidence to back this claim. An experimental evaluation of this claim revealed that this practice was actually more harmful to captured fish (Trahan et al. 2020). Further, misinformation from anglers about fishing regulations on social media can negatively influence perceptions within the fishing community and managers may find it necessary to provide 
correct information on the social media fora. Moreover, if managers engage in "putting out fires" on social media, they have to balance if they are managing the vocal minority or the silent majority (the two groups may or may not be aligned). Traditional surveys with a random sampling frame are needed to sort this out (e.g. Jones and Pollock 2012).

Information sharing among anglers can be voluntary, e.g. when anglers discuss and share fishing spots in open or closed Facebook groups. However, unwanted information sharing can also occur which may lead to controversy related to potentially revealing prime fishing locations (discussed above) and diluting the sporting nature of the act of fishing, overall. In an interesting example from Ontario, Canada, an angler posted an image of a trophy-sized fish that they caught in a "secret" lake within the $7653 \mathrm{~km}^{2}$ Algonquin Provincial Park. Another angler filed a freedom of information request for the angler's camping permit in an attempt to learn which lakes he had fished in (https://www.cbc.ca/news/canada/ thunder-bay/foi-request-fishing-spot-1.4232556). If images contain identifying landmarks or are not scrubbed of meta-data, then they may provide clues or detailed information on where fishing occurred; for example, many cameras and cellular phones automatically georeference photographs, which can reveal locations to others. Regardless of the form, the rapid sharing of data via social media can lead to rapid increases in fishing pressure in particular areas. In its extreme, this pressure can result in localised overfishing with associated ecosystem and social consequences, e.g., loss of angler utility (e.g. Arlinghaus et al. 2017b). Alternatively, data sharing on social media may increase public awareness of fish and fisheries, potentially leading to positive public perceptions of fish that could influence pro-environmental behaviours and/or greater support for policies that support their conservation (Danylchuk et al. 2018).

A recent study argued that the future governance of recreational fisheries would benefit from a stronger organization of anglers, e.g. angler clubs and associations (Arlinghaus et al. 2019). In some countries (e.g. Denmark), anecdotal information suggests that member numbers in angling clubs have decreased in recent years. Historically, angling clubs have had an important role in facilitating information sharing among anglers, e.g. about where and when to fish, what to fish with and where to buy access to waters. It is easy to imagine that much of the information previously shared at club meetings and other fishing club gatherings has been replaced by social media fora, which to some extent has made fishing club memberships superfluous. Anecdotal information, e.g., from angling clubs in Denmark suggests that younger people in particular are not joining fishing clubs, which could relate to a generation of "digital natives" i.e. people born in or after the 1990s. This so-called "Generation C" live "online" most of their waking hours. Here, they participate in numerous social networks with several hundred or more contacts, generate and consume vast amounts of formerly private information, and carry with them a sophisticated "personal cloud" that identifies them in the converged online and offline worlds (https://static1. squarespace.com/static/5481bc79e4b01c4bf3ceed80/ t/548775e3e4b04e84900ab161/1418163683616/Rise_ Of_Generation_C.pdf). Time will show if and how the social role and the information-sharing-role of angling clubs will be replaced by online organised fora. Alternatively, a counter response may emerge wherein personal, face-to-face relationships again will increase in attractiveness, paving the way for increased recruitment to angling clubs.

Recreational fisheries often suffer from data poverty (Arlinghaus et al. 2019), and net scraping from social media can provide novel information about the species present (e.g. seasonal patterns) in a water body and to some extent the length/weight information. Similar, data mining, e.g. the process of discovering information, patterns in datasets that involves different machine learning, can provide knowledge to managers from data poor fisheries. An example is provided by Sbragaglia et al. (2020), who used YouTube data mining to explore differences in harvest patterns and social engagement between recreational anglers and spearfishers. Although net scraping and data mining are useful tools, there are also challenges with the methodology, e.g. legally, practically, and ethically (Monkman et al. 2018b).

\section{Smartphones}

\section{The technology and its application}

It stands to reason that most recreational anglers (especially the next generation of anglers) have a smartphone with them while fishing. Smartphone 
ownership is approaching $50 \%$ globally and $80 \%$ in advanced economies (www.pewresearch.org/global/ 2019/02/05/smartphone-ownership-is-growing-

rapidly-around-the-world-but-not-always-equally/), and most users depend on the technology for daily life (e.g., Ward et al. 2017; Foreman-Tran et al. 2020). Smartphones are a net safety benefit (Yared et al. 2015), allow anglers to take photos and monitor conditions, and can extend fishing opportunities by allowing anglers to remain available and productive while away from the home or office (Kalkbrenner and McCampbell 2011). Smartphones are also a convenient interface with, and extension of, many of the technologies that are featured in this paper (e.g., cameras, ROVs, navigational equipment, smart devices). Particularly relevant to fisheries management and policy are the many applications (also known simply as "apps") that support private or public catch logging, and specialized social networking (Venturelli et al. 2017; Bradley et al. 2019). Catch log fields vary among these apps (Venturelli et al. 2017), but typically include date, time, location, conditions, method of fishing (e.g., boat vs. shore, type of lure), species, size, and fate. These data are often summarized as personal and relative statistics, and used in aggregate to offer popular features such as fishing reports, forecasts, and maps that can inform decisions about where, when, and how to fish. Other common features include digital licensing, regulation information, species identification, and virtual tournaments.

\section{Implications for recreational fisheries governance}

Smartphone use by anglers is both a challenge and an opportunity for fisheries science and governance. For example, using smartphones to photograph or videotape fish and/or record catch information can prolong handling times, and may translate into higher rates of post-release mortality (Joubert et al. 2020). This effect of smartphone use is most likely among species or sizes that are most vulnerable to catch-and-release mortality, and in high-effort, catch-and-release fisheries. However, estimating the impact of smartphone use on any fishery requires careful study - not only to establish a relationship between handling time and release mortality - but to understand how this relationship varies with important ecological conditions (e.g., temperature) and other catch-and-release practices (e.g., hook characteristics) (Joubert et al. 2020).
Management options to address incremental mortality associated with using smartphones to document fishing catch include angler education, smartphone regulation, and effort reduction; however, identifying the most appropriate combination of actions will likely require human dimensions research and adaptive management.

Using smartphones to share photographs and data in near real time has important management and policy implications. The traditional image of recreational fishing as a solitary and secretive pursuit does not apply to the growing number of anglers who freely post catch information to social media. Angler apps are a popular and specialized form of social networking that emphasizes data sharing, discovery, and application in near real time. As described in the Social media section, access to a wealth of up-to-date information about where and how anglers are having success can concentrate effort and improve catch rates (see Schramm et al. 1998 for an "analog" example). A sudden influx of additional anglers can overwhelm the capacity of individual controls on angler effort and harvest (e.g., bag and length limits) to limit overall effort and harvest (Post and Parkinson 2012). Thus, smartphone use has the potential to strain local stocks and associated ecological systems and economies. Although preventing anglers from sharing catch information is a non-starter in most jurisdictions, it may be possible to limit the impact of the information that is shared through apps by legislating spatial or temporal averaging, or delayed reporting (Lindenmayer and Scheele 2017). As with many of the technologies that are described herein, smartphones can be used to inform anglers about stricter controls on effort and harvest - either in the form of reduced bag limits and/or altered length limits, or more direct approaches such as quotas, and tag systems. If the fishery is made up of numerous lakes, rivers, and/or streams, then these controls could be implemented as part of a regional management plan (Lester et al. 2003; Carpenter and Brock 2004; Hunt et al. 2011).

The information that anglers share via their smartphones is also a potentially valuable source of fisherydependent data for both real time and post hoc analysis. This potential is already being realized among specialized social networking apps related to bird watching (Callaghan and Gawlik 2015; Kain and Bolker 2019) and cycling (Sun et al. 2017; Lee and Sener 2019). The value of smartphone data to a 
particular fishery will depend on the type, amount, and quality of the information that is collected, its availability to researchers and managers, and how it is analyzed and applied within management and policy frameworks (Venturelli et al. 2017). Initial research into the potential value of angler app data is both informative and encouraging. Papenfuss et al. (2015) used the movement patterns of individual anglers to reveal connectivity patterns among lakes in Alberta, Canada, and found a strong regional correlation between app- and mail survey-based estimates of effort that was not evident at the scale of individual lakes. Similarly, Jiorle et al. (2016) found that appand creel-based catch rates were similar for some species when the app data were clustered by county. Data from this app have been incorporated into stock assessments for common snook (Centropomus undecimalis) (Muller et al. 2013). Finally, Liu et al. (2017) combine app and creel data within a capture-recapture framework to improve red snapper (Lutjanus campechanus) catch estimates in the Gulf of Mexico. In addition to serving as digital catch logs, smartphone apps can provide data that generate insight into angler behaviour, human dimensions, the economics of recreational fishing, aquatic ecology, the spread and impact invasive species, and climate change (Jarić et al. 2020). Realizing this potential will require cooperation among anglers, agencies, institutions, and industry to establish a large and reliable data stream. It also requires a strong commitment to research that identifies the strengths, weaknesses, benefits, and limitations of smartphone data (Venturelli et al. 2017).

Smartphones can change the way that anglers and agencies interact by creating opportunities for the twoway flow of information in near real time. For example, app use at certain places and times can trigger alerts that are designed to improve compliance with regulations (Mackay et al. 2018, 2019), encourage conservation behaviour (e.g., best handling practices, invasive species control), or improve safety. Alerts can also prompt anglers to report specific and accurate information, or complete surveys in support of management or research. Conversely, anglers can use their smartphones to push information to agencies; not only catch and effort data, but a diversity of timely and potentially relevant observations such as fish kills, tags or fin clips, injuries, poaching events, habitat degradation, (www.ishbrain.com/blog/fishbrain/ collecting-trash-from-us-waters), and the presence of predators. Smartphones also facilitate direct collaborations between anglers and agencies (Mazumdar et al. 2018). Citizen science examples that rely heavily on smartphone apps include the Angler Action (www. angleraction.org) and Fangstjournalen (www. fangstjournalen.dtu.dk) catch logs, and a partnership between the U.S. Fish and Wildlife Service and the Fishbrain app (www.fishbrain.com) that encourages anglers to track invasive species (www.landscape partnership.org/news/fishbrain-and-u.s.-fish-and-wild life-service-partner-to-create-app-powered-citizenscience-engagement-opportunity-tracking-endangeredspecies). With enough research and participation, the rapid, two-way flow of information between anglers and agencies could even support an adaptive management approach that adjusts allowable harvest (fish size and number) in near real time based on the estimated impact of cumulative harvest on target reference points (Venturelli et al. 2017; Bradley et al. 2019). Although the emergence and success of such a management scheme is debatable, it illustrates the extent to which smartphones can re-shape fisheries management and policy. A more likely and immediate outcome of angler-agency communication and collaboration via smartphones is a much-needed increase in angler participation in the management process as well as increasing angler awareness about fish biology, fish care, and various regulations (Arlinghaus et al. 2019).

\section{Potential threats and opportunities of technology}

Here we synthesize potential threats and opportunities arising from technology. Although this section is somewhat conceptual, it draws upon and synthesizes examples from Sect. 2 above and thus includes minor redundancy. We also preface this section by noting that technology and its impacts and regulation have been explored for decades in the commercial sector (Eigaard et al. 2014; Palomares and Pauly 2019; Scherrer and Galbraith 2020) and thus there is much that could be learned from those experiences (e.g., see Cooke and Cowx 2006 for contrasts of the recreational and commercial sector) but that is largely beyond the scope of this paper. 
Technology and Anglers

Anglers have a tremendous amount of technology they can access for use in recreational fisheries, from selecting a fishery, down to handling a captured fish (Fig. 3). Just like in all aspects of civilization, technological innovations will spread in a predictable fashion in the angling community (Arlinghaus 2004). The basic model describing the information uptake and spread of innovations was presented in the landmark work by Rogers (1962). Accordingly, any type of innovation will initially only reach a small fraction of innovators, which is then recognized by a somewhat larger fraction of potential adopters (Fig. 4). Only after time will the innovation become fashionable among the majority and reach the mainstream stage at which the innovators have likely already started to kick in further innovations that revive the cycle. The situation in recreational fisheries is most likely to follow this path, although no primary research exists.

Although it is difficult to generalize across all recreational fisheries, most innovations will either make the fishing activity less challenging (e.g., by increasing the ease of line retrieval) or they will make fishing more effective in terms of catch per time. The outcomes related to a catch-enhancing innovation may follow several paths. In general, there has been very little research on this topic, but there is evidence from anglers in Minnesota that they are generally supportive of technology use even if a given angler does not use technology to aid in fish capture (Bruskotter and Fulton 2008). This is likely also age-dependent, with gear innovations being more likely to penetrate younger generations. An innovation might also facilitate the catch of memorable (e.g., trophy sized) fishes, or make the catch more predictable and consistent. One example may be the innovation of boilie fishing for specialized carp (Cyprinus caprio) in the 1980s by a small group of avid English carp fishers (Clifford 1992; Arlinghaus 2007). These anglers invented a bait that was selective for large carp, and a rig system that improved the hook up without a need to pay attention to the bite (self-hooking through the so-called bolt rig, Rapp et al. 2008). This bait and rig innovation contributed to a dramatic increase in catch sizes and numbers of carp (Clifford 1992). At first, boilie fishing was done by a small fraction of closed, connected, and highly avid innovators-many of whom later developed businesses marketing boilies and other carp fishing equipment. By the early 1990s, early adopters came in that brought boilie fishing to the angling media on mainland Europe, creating a boom and shift to the early majority by the late 1990s. Today we are seeing the proliferation of different fishing techniques (e.g., micro fishing https://microfishing. $\mathrm{com} /, \quad$ https://www.fieldandstream.com/obsessivecult-microfishing-life-listers/) that indicates anglers strive to experience new fishing opportunities.

When thinking through the outcomes of such strongly catch-increasing innovations that are originally only used by a small minority, what are the possible broader effects of such innovations in angling communities? Given that more specialized anglersanglers who are more invested, emotionally involved, skilled, and avid (Bryan 1977)—show higher degree of media interactions and willingness to experiment with innovations that could make their fishing even more effective (Ditton et al. 1992), we can safely assume that the more avid and involved anglers most likely belong to the early adopters of the innovation diffusion model. In fact, as in the case of the carp anglers (Clifford 1992), key innovations may initially preferentially circle in like-minded, tight and modular networks (i.e., networks that are dense but only loosely or not connected at all to other nodes). The innovation may then quickly inspire a selected group of people that care and have the energy to invest-the specialized anglers. Further, these anglers may be those most affluent as initially innovations can be costly until adoption becomes sufficiently high that the technology is mass-produced. Experimental research has shown that the more involved anglers also have higher skill and thus in general are able to achieve higher catch rates or catch rare large fish with greater probability than less involved anglers (Monk and Arlinghaus 2018). If the gear innovation provides this catch rate benefit for the more involved angler segment, an effective gear innovation will further increase the inequality of catch rates that is generally present among anglers (Baccante 1995; Seekell et al. 2011).

The same argument applies to access to unexploited fishing sites, which may be reachable with technological innovations such as more powerful boats, improved fish finding technology, and drones. These innovations will most likely also be taken up by specialized anglers, who are in the minority, but their 
boost in catching power will further increase the inequality in catch rates among the wider population of anglers. This level of inequality may increase through specialized anglers practicing catch-andrelease and thus increasing the number of "experienced" fish in the population that are harder to catch (Arlinghaus et al. 2017a). Indeed, fish can also respond to the continuous exposure to the new bait or lures and reduce their reactivity to the gear (as, for example, shown in hook avoidance learning in carp exposed to boilies, Monk and Arlinghaus 2017). Therefore, the fitness benefit that is offered by the tackle innovation maybe reduced as its use in the angler community spreads-a process known in evolutionary biology as frequency dependent selection (e.g., Altenberg 1991). Thus, even if the majority of anglers would at some point also adopt the tackle innovation, it is very likely that the catch rate benefits of this strategy would then no longer hold, further increasing dissatisfaction among the majority, particularly if catch per expenditure decreases.

To conclude, achieving sufficient catch is a major determinant of a satisfied angler trip across many angler populations (Arlinghaus 2006; Beardmore et al. 2015). Therefore, gear innovations have the potential to substantially increase the satisfaction of a minority, and actually reduce satisfaction substantially among the non or late-adopting majority, in particular acknowledging that the elevated catch rates of the minority are unlikely to not get noticed (e.g., due to social media or shying). Humans typically develop feelings of perceived unfairness through a process of direct comparison with others (Adams 1965; Mussweiler 2003). The argument proposes the insofar untested hypothesis that effective gear innovations will initially psychologically foster feelings of relative depreciation and reduce, rather than increase, overall angler satisfaction in the wider angler community.

More generally, innovation dynamics in recreational fisheries may contribute to the development of cultural conflict and foster processes of social identity and in-group vs. out-group biases. It is likely that the late adopters often encompass more traditional, possibly elderly, technologically less prone demographic segments in society. These segments may take value in fishing from being surrounded by like-minded anglers who use traditional technology. These anglers might reject the life-style of the early adopters on principle, and be hesitant to engage in the "new stuff" that the younger generations are using. Social identity may then create power imbalances and in fact even initiate selective regulations as, for example, witnessed by the specialized carp anglers by the majority of more traditional club anglers in Germany (Arlinghaus 2007). There were ample anecdotal examples where highly effective specialized carp anglers were selectively constrained by angling clubs in Europe institutionalizing bans on boilies or specific equipment (e.g., tents) that carp anglers needed to fish effectively (Arlinghaus 2007). The fact that carp anglers usually release their catch and thus there is no true competition for common pool resources strongly suggests that the regulations were tailored to curtail the innovation per se, and were caused by social identity issues and rejection of life-style forms. These bans did not prevent early adoption of the approach, but instead led to angler displacement from selected carp fisheries to others where their equipment and methods were tolerated.

The ultimate result of innovation might be the evolution of conflict and the exertion of power imbalances. The early adopting minority has the power of maintaining and keeping catch rates high, while the late adopting majority typically hold the decision or lobby-making power, creating substantial tensions that need to be managed through communication and spatial and temporal zoning. Examples of these tensions are many (e.g., among specialized and non-specialized anglers, shore-based and boat-based anglers, those that invest in prebaiting versus those that spy on pre-baited spots, spearfishers and regular anglers, etc.). Many of these conflicts have to do with different use of technology and perceived unfairness either in the chase per se or in the way the quarry is attracted and captured.

There are more biological issues that gear innovations can bring about. Specifically, certain highly effective catch innovations adopted by a minority of highly avid and skilled innovators can foster overfishing once widely adopted. First, gear innovations may maintain high catch rates even when fish stocks decline, creating hyperstability in catch rates (Post et al. 2002; Maggs et al. 2016; Dassow et al. 2020). Hyperstability reduces the index value of catch per unt. In addition to the effect of gear effectiveness per se, hyperstability maybe further created through effort sorting, where lowly skilled (non-adopting angler) leave a fishery early in the process of the stock being 
fishing down, while being substituted by skilled anglers that maintain high catch rates even with dwindling stocks (Ward et al. 2013). The result is an "illusion of plenty" (Erisman et al. 2011), until the stocks are fished down and collapse (Post et al. 2002). Hyperstability also fosters feeling of inferiority among those that do not benefit from the maintenance of high catch rates and may create management conflicts where a group of low catch rate anglers demand action (such as stocking to deal with their low catch rates), while the group of effective anglers sees little need to act because the stock has not appeared to collapse for them. Such collapses may even happen with total catch-and-release policies. For example, it is now fashionable to engage in "pelagic" fishing for freshwater top predators (e.g., zander (Sander lucioperca), northern pike (Esox lucius)) in central and northern Europe's deep and large lakes. The gear innovation was high powered fishing boats equipped with highly sophisticated fish finding equipment, and the technique of vertical lure fishing for individual (large) fish seen on the radar. Although the norm of catch-andrelease is prevalent among the more specialized lure fishers, the fish are very effectively targeted and may be repeatedly exposed to stress, barotrauma and other injuries. This repeated catch-and-release can lead to population-level impacts if total effort is high (Coggins et al. 2007; Johnston et al. 2015). The situation is similar to the roving bandit metaphor prominent in marine fisheries (Berkes et al. 2006) where a previously inaccessible deep water, long distance resource-large predators in open water in large lakes-suddenly become easy targets for a small group of a highly geared-up anglers. Social media accounts show these anglers are ardent promotors of catch-and-release and are convinced their fishing is less harmful than a catch-and-kill fishing practice. Yet, pikeperch and other physoclists are quite sensitive to hooking mortality and barotrauma when brought up from water depths greater than $10 \mathrm{~m}$ (Talmage and Staples 2011). In addition, the continued catch and release of lure-based predator fishing leads to information spread amongst fish under water, creating a timidity syndrome that reduces catchability (Arlinghaus et al. 2017a). The cumulative impact might be a surprising collapse of once abundant resources despite catch-and-release, and this outcome has anecdotally happened in some once popular large lake angling fisheries for top predators in Sweden and elsewhere (Tibblin, personal communication).

\section{Technology and Fish}

Innovation in seafaring, fish finding, and fish capture technology has had a significant impact on global fish stocks. Fishing is a multi-billion dollar industry and technology is playing a massive role in assisting with fish capture with many innovations originating in commercial fisheries. Pelagic commercial fisheries, for example, are supported by a network of $>100,000$ drifting fish aggregating devices (FADs) outfitted with GPS loggers and sometimes acoustic echosounders that can remotely monitor the abundance of fish under the FAD for fishers (Moreno et al. 2016). Increasing availability of these global observing technologies may lead to their potential use by recreational fisheries that would greatly benefit from knowledge about the availability of fish for capture. Development of other tools such as cameras, drones, remotely operated vehicles, and scientific telemetry devices (see Cooke et al. 2016) have the potential to provide assistance to fishers that can increase investments in fishing and enhance capture rates. Whereas some technological innovations have the potential to enhance the sustainability of some fisheries by decreasing the costs of travel (i.e. fuel) and increasing the selectivity of fishing operations by fishing on target species with greater discrimination, there are clearly consequences to fishers becoming more efficient predators that can have negative consequences for fish populations and individuals.

Most fish populations are usually resilient to modest fishing (Froese et al. 2017), and management models tend to split a population into a harvestable surplus and a replacement population, leaving enough individuals to successfully spawn and achieve replacement (Punt and Smith 2001). Fishing efficiency can range from inefficient, when fishers are entirely uninformed and catches are random, to highly efficient. Technology is most likely to improve catches, whether marginally or significantly, which can contribute to overfishing. Recreational anglers have the capacity to target fish with such high efficacy stocks might collapse (Post et al. 2002, 2008; Cooke and Cowx 2004). These effects are likely to be exacerbated by technological advances or by range contractions and ability of fishers to find even smaller abundances 
(Dassow et al. 2020). There should be concern about the potential for how improved efficiency could affect some fishing systems, particularly those that are already vulnerable due to smaller populations. Technology thereby contributes to allowing fishers to catch more fish at smaller density, obscuring declines, and accelerating collapse (Harley et al. 2001). Small prey populations in nature generally tend to reduce predation rates, allowing recovery, but when fishers continue to efficiently remove a small number of remaining individuals, it can drive depensation and inhibit recovery (Myers et al. 1995). Theoretically, tools such as fish finders and drones that help anglers to target individuals that are otherwise challenging to find and catch can have a disproportionately large impact on an already stressed fish population.

Note that collapse may also be just perceived as fish become harder and harder to catch through experience and selection (Koeck et al. 2019, 2020)-a process known as the "timidity syndrome" (Arlinghaus et al. 2017a). In particular large, repeatedly captured fish might develop a very shy behavioural style, effectively reducing exposure to anglers and creating a feeling of demise of the stock (Alós et al. 2019).

Fishing is non-random, and recreational fisheries generally seek individuals from specific species, and sometimes even specific size classes or sexes within species (i.e., when there are harvest regulations imposed by fisheries managers; Lennox et al. 2017). Technology provides a tool for enhancing selectivity, for example, when recreational anglers use cameras or echosounders to observe the fish available in their vicinity, they can adjust their searching behaviour to target preferred species or trophy individuals. Targeting with a rod and reel that catches one fish at a time is inherently different from targeting with nets; with rod and reel, targeting can decrease overall catch rates and minimize bycatch but drive a more extreme phenotypic selection gradient that will generally be biased against large individuals (Pope et al. 2005). Gear selectivity that preferentially removes large individuals is implicated in evolutionary effects on target populations (Jørgensen et al. 2007). Additionally, lure based angling gear may select on aggression and other behavioural traits independent of size selection (Sutter et al. 2012; Arlinghaus et al. 2017a) depending on the intensity of fishing mortality (the sum of harvest and release mortality). Moreover, technological innovations have contributed to bycatch reduction in fisheries
(Campbell and Cornwell 2008) and have the additional potential to assist fisher selectivity and avoid non-target species or sizes that would otherwise be captured by non-selective fishing.

\section{Technology and management}

Technological development and innovation is happening at an increasingly rapid pace, and anglers are using this to access new fishing opportunities, more effectively target fish, record and share information, and improve the welfare of captured fish. This use of new technology affects both catch rates and fishing mortality, so has a direct impact on management of fisheries (Eigaard et al. 2014; Bradley et al. 2019). Traditionally, the management of recreational fisheries has been a reactive process, where data are collected and used in an assessment to inform future regulation (FAO 2012). Regulation is usually part of an annual cycle, but there are examples of more adaptive management techniques used in relation to season length. In addition, there are limited management measures that can be used to reduce fishing effort and mortality including: bag limits, size limits, gear restrictions, and area or seasonal closures (FAO 2012). Whilst there will be a place for these traditional approaches, it is possible that these approaches will become less effective in future as technology leads to better targeting of fish by anglers that increases catch rates and pressure on fish. The main modes of managing commercial fisheries are through fleet capacity, limiting effort, or setting total allowable catches, but all are impacted by technology due to decoupling nominal and actual capacity, ability to predict changes in catchability, and relying on good estimates of catch per unit effort to use in assessments, respectively (Eigaard et al. 2014). As a result, more adaptive management systems and adaptive monitoring systems will be needed that embrace the new technology and innovation to provide effective local management, control, and compliance in real time (e.g. Dunn et al. 2016; Little et al. 2015; Maxwell et al. 2015; Bradley et al. 2019). Technology provides both significant challenges, particularly in terms of rapid change, but also has allowed management paradigms to adapt and create new roles for different actors in a way that has not previously been possible (Eigaard et al. 2014; Bradley et al. 2019). 
The overall goals of fisheries management are to protect fisheries resources through sustainable exploitation of the stocks by maintaining fishing mortality at a level which will not damage the stock (FAO 1997), optimize angling quality and compromise food security (e.g. Jennings et al. 2016; FAO 2012). Much of the technology and innovation described above has an impact on catch rates and fishing mortality (Bradley et al. 2019). This could reduce the efficacy of management strategies that limit the time spent fishing or increase the proportion of anglers taking their bag limit. For example, more effective targeting of existing fisheries through improved gear (e.g. tackle), use of technology to locate fish (e.g. sonar), or forecasts (e.g. weather, catch predictions) would impact the benefits of management measures. In addition, the use of smartphone apps can lead to 'crowd fishing' wherein anglers are use apps to identify current hotspots. Traditionally, small groups (e.g. friends, clubs) might share information, but this can now happen on much larger scales through social media and apps (e.g. millions of users of Fishbrainhttps://fishbrain.com/). It can also highlight new fishing opportunities to a much larger audience, thereby leading to increasing targeting of new species.

Despite the potential to change fishing effort and catches rates, there are many potential benefits of technology that can be a useful tool for managers. It is possible that fisheries scientists and managers can use the same technologies to improve the quality and timeliness of data collected, identify new issues, understand responses to management, engender compliance, and enforce management measures.

Enhancing the evidence base is key to making effective decisions (Beddington et al. 2007). Web scraping and text mining can be used like an early warning system for diseases (e.g. Collier et al. 2008; Polgreen et al. 2008; Jarić et al. 2020), to identify new species that are arriving in waters, and to highlight the need for management action (e.g. Atlantic bluefin tuna). Web scraping and apps have the potential to reduce uncertainty in fisheries assessments and increase effective decision-making, once the characteristics of the data and its uses are understood (e.g. Papenfuss et al. 2015; Jiorle et al. 2016; Venturelli et al. 2017). Smartphone apps provide many great opportunities for real-time local adaptive management including quota-based systems (Venturelli et al. 2017; Bradley et al. 2019) and more general fostering ability to interact with stakeholders, inform them and gather input before decisions are taken. Geofencing can be used to identify when people are near to waterbodies, provide information about local regulations, and provide the reporting needed for quota-based approaches (e.g. red snapper in the Gulf of Mexico). For example, data collected using the iSnapper apps and traditional US surveys has been showed to be of reasonable quality (e.g. Stunz et al. 2014; Liu et al. 2017) and is used to support data collection for assessment and management (https://www. sportfishcenter.org/outreach/isnapper-app). Even if biased, these approaches can be used to provide trends in catches that could be used as indices in stock assessment (e.g. Richardson et al. 2006). For example, discard information for common snook (Centropomus undecimalis) has already been included in state stock assessments for Florida (Muller and Taylor 2013).Technology could also be used to react to live situations, for example, decisions about retention and release of fish and water-body specific management. The ability to use new technology to connect with anglers can also be used to understand behavioural responses (e.g. Martin et al. 2014; Shiffman et al. 2017) and engender compliance with regulation (Venturelli et al. 2017). For example, pushing messages about conservation orientated behaviour and good handling practices could be used to enhance positive behaviours and change social norms (e.g. nudge-Mackay et al. 2018, 2019). In addition, artificial intelligence methods could be used to assess compliance with regulations through photographs or videos posted on social media (e.g., Belhabib et al. 2016; Sbragaglia et al. 2020). The diverse and dispersed nature of recreational fisheries, especially those from the shore, make enforcement a significant challenge. It is possible that technology could be used alongside enforcement officers to identify specific areas to target. This could use existing CCTV (e.g., Norris and McCahill 2006), cameras used to monitor effort (e.g., Hartill et al. 2020) or satellites (e.g. Waluda et al. 2011; Dunn et al. 2018; Keramidas et al. 2018).

These examples highlight that technology and innovation have an important role in developing real-time effective management of recreational fisheries at local scales. However, management agencies are generally slow to adopt new technologies, and may even be considered 'laggards' (see above and Fig. 4). 
This is likely to lead to a mismatch between the benefits to anglers adopting technology and the speed of response of the management system to react to the technologically driven changes (especially new uses of existing technology). To address this, it is important that government agencies embrace and use technology to support conservation of fish stocks, but it is often not possible for management agencies to do this on their own. There are four major challenges that relate to costs, legal and bureaucratic barriers, data standards, trust and buy-in (Bradley et al. 2019). In addition, innovators of new technology do not generally sit within these organisations, but are found in tech companies and the angling community (Bradley et al. 2019). There is often mistrust between communities that impacts on management especially related to electronic data capture systems (e.g. Mangi et al. 2015), but technology has the potential to provide solutions that balance transparency and privacy (e.g. BLOCKCHAIN; Probst 2019). The only solution to this is for the angling, science, and management communities to work together to embrace technology and proactively co-develop management systems that engender conservation-based behaviours and responsible fishing (Wilson et al. 2003). This will require a dramatic change in approaches from the reactive to proactive, but also the development of transdisciplinary methods that bring together fisheries managers, fisheries biologists, computer scientists, fishing organisations, and the fishing industry. It is the responsibility of all actors to engage with the development of novel co-management systems to generate robust data, assessment, and management, and enhance behaviours that will conserve fish stocks for future generations. The advent of new technology simply makes it more important that anglers, the angling industry, and the decision-makers understand their responsibility and act accordingly to ensure a sustainable future for recreational fisheries (Cooke et al. 2019). Moreover, one of the reasons that management agencies may be perceived as being "asleep at the wheel" is because many innovations have proprietary information with limited evidence of demonstrated benefits from focused research. Increased sharing of knowledge by industry partners and research focused on evaluating the effects of different technologies on fish and fisheries would enable management authorities to be able to engage in evidence-based decision making in a more timely manner.

\section{Conclusion}

The recreational fishing community has access to a diverse suite of technologies that help (or are purported to help) anglers locate, catch, and handle fish. There are a number of ethical issues that certainly emerge with respect to "giving fish a sporting chance" (e.g., Hummel and Foster 1986) and providing unfair advantages to certain anglers that adopt various technologies. It behooves natural resource management agencies to pay close attention to innovationsboth those that have already been adopted-or those on the horizon-given their potential to influence the sustainability of recreational fisheries (Elmer et al. 2017). In general, there are many research needs (Holder et al. 2020) and very little empirical research on the effects of technology on recreational fishing outcomes (but see Feiner et al. 2020 for example). There is evidence of technology creep that enhances fish capture success along with tools that could influence the selectivity of a given fishery-something observed in the commercial realm for decades (see Marchal et al. 2006; Eigaard et al. 2014). An important message here is that resource management agencies need to share their experiences and that scientists should more intensively study the impact of innovations in recreational fishing. There is a strong likelihood that, for any given technological issue, some agency has already had to deal with it. Those do not necessarily mean that all other organizations should emulate them precisely, but it does provide an opportunity to learn, which is a powerful approach to informing regulatory options (Radomski et al. 2001). There is also opportunity for fisheries management agencies and recreational fisheries scientists to keep abreast of the latest innovations by attending industry trade-shows, monitoring social media, video sharing sites, online forums, and traditional media (e.g., fishing magazines) and generally being engaged with the sector and design clever experiments to learn from novel innovations as they spread. The last thing that one wants is for a natural resource management agency to be in a position where their response is "we didn't see that coming" whereby an activity that is potentially detrimental or one that could substantially 
improve business has already been fully embraced and normalized by the recreational fishing community and suddenly has to be regulated (Fig. 4). This is an exciting time for the recreational fishing industry, but with that comes additional challenges for fisheries managers (Arlinghaus et al. 2016; Brownscombe et al. 2019). We hope that the ideas presented here will help the fisheries management community be proactive and responsive to the rapidly evolving recreational fishing sector (Elmer et al. 2017) for the benefit of the fish populations that they manage as well as the anglers that depend on them.

Acknowledgements Cooke is supported by Genome Canada and the Natural Sciences and Engineering Research Council (NSERC) of Canada and Genome Canada. Twardek is also supported by NSERC. Arlinghaus received funding through the European Union (European Maritime and Fisheries Fund) and the State of Mecklenburg-Vorpommern (Germany) (Grant MVI.18-LM-004, B 730117000069), and the German Federal Ministry of Education and Research (Grants 01LC1826E and 033W046A). Skov is supported by the European Commission Data Collection Framework and the Danish Rod and Net Fish License Funds. Danylchuk is supported by the National Institute of Food and Agriculture, U.S. Department of Agriculture, the Massachusetts Agricultural Experiment Station, and the Department of Environmental Conservation at U Mass Amherst. We are grateful to several referees including Bruce Mann.

Data availability and sharing statement Data sharing is not applicable to this article as no new data were created or analyzed in this study.

\section{Compliance with ethical standards}

Conflict of interest We acknowledge the following actual or perceived conflicts of interest: All of the authors are avid anglers; Diggles has been involved in the development of fish attractants for commercial purposes.

\section{References}

Adams JS (1965) Inequity in social exchange. In: Berkowitz L (ed) Advances in experimental social psychology, vol 2. Academic Press, New York, pp 267-299

Alós J, Palmer M, Grau AM, Deudero S (2008) Effects of hook size and barbless hooks on hooking injury, catch per unit effort, and fish size in a mixed-species recreational fishery in the western Mediterranean Sea. ICES J Mar Sci 65(6):899-905

Alós J, Campos-Candela A, Arlinghaus R (2019) A modelling approach to evaluate the impact of fish spatial behavioural types on fisheries stock assessment. ICES J Mar Sci 76(2):489-500
Altenberg L (1991) Chaos from linear frequency-dependent selection. Am Nat 138:51-68

Arlinghaus R (2004) A human dimensions approach towards sustainable recreational fisheries management. Turnshare Ltd., London, p 400

Arlinghaus R (2006) On the apparently striking disconnect between motivation and satisfaction in recreational fishing: the case of catch orientation of German anglers. North Am J Fish Manag 26(3):592-605. https://doi.org/10.1577/ M04-220.1

Arlinghaus R (2007) Voluntary catch-and-release can generate conflict within the recreational angling community: a qualitative case study of specialised carp, Cyprinus carpio, angling in Germany. Fish Manag Ecol 14(2):161-171

Arlinghaus R, Cooke S (2009) Recreational fisheries: socioeconomic importance, conservation issues and management challenges. In: Recreational hunting, conservation and rural livelihoods: science and practice, pp 39-58

Arlinghaus R, Cooke SJ, Cowx IG (2010) Providing context to the global code of practice for recreational fisheries. Fish Manag Ecol 17(2):146-156

Arlinghaus R, Cooke SJ, Sutton SG, Danylchuk AJ, Potts W, Freire KDM et al (2016) Recommendations for the future of recreational fisheries to prepare the social-ecological system to cope with change. Fish Manag Ecol 23(3-4):177-186

Arlinghaus R, Laskowski KL, Alós J, Klefoth T, Monk CT, Nakayama S, Schröder A (2017a) Passive gear-induced timidity syndrome in wild fish populations and its potential ecological and managerial implications. Fish Fish 18:360-373

Arlinghaus R, Alós J, Beardmore B, Daedlow K, Dorow M, Fujitani M, Hühn D, Haider W, Hunt LM, Johnson BM, Johnston F, Klefoth T, Matsumura S, Monk C, Pagel T, Post JR, Rapp T, Riepe C, Ward H, Wolter C (2017b) Understanding and managing freshwater recreational fisheries as complex adaptive social-ecological systems. Rev Fish Sci Aquac 25:1-41. https://doi.org/10.1080/ 23308249.2016.1209160

Arlinghaus R, Abbott JK, Fenichel EP, Carpenter SR, Hunt LM, Alós J et al (2019) Governing the recreational dimension of global fisheries. Proc Natl Acad Sci 116(12):5209-5213

Baccante D (1995) Assessing catch inequality in walleye angling fisheries. North Am J Fish Manag 15(3):661-665

Baiamonte JB, Wegner CD (2010) Fish dehooking device. U.S. Patent No. 7,818,914. U.S. Patent and Trademark Office, Washington, DC

Barillas K, Fernandez S (2019) The sky's the limit: drones for social good. In: Proceedings of the 126th annual conference of the American society of engineering education

Beardmore B, Hunt LM, Haider W, Dorow M, Arlinghaus R (2015) Effectively managing angler satisfaction in recreational fisheries requires understanding the fish species and the anglers. Can J Fish Aquat Sci 72:500-513

Beddington JR, Agnew DJ, Clark CW (2007) Current problems in the management of marine fisheries. Science 316(5832):1713-1716. https://doi.org/10.1126/science. 1137362

Belhabib D, Campredon P, Lazar N, Sumaila UR, Baye BC, Kane EA, Pauly D (2016) Best for pleasure, not for business: evaluating recreational marine fisheries in West 
Africa using unconventional sources of data. Palgrave Commun 2:15050. https://doi.org/10.1057/palcomms. 2015.50

Bellquist L, Beyer S, Arrington M, Maeding J, Siddall A, Fischer P, Hyde J, Wegner NC (2019) Effectiveness of descending devices to mitigate the effects of barotrauma among rockfishes (Sebastes spp.) in California recreational fisheries. Fish Res 215:44-52

Berkes F, Hughes TP, Steneck RS, Wilson JA, Bellwood DR, Crona B et al (2006) Globalization, roving bandits, and marine resources. Science 311(5767):1557-1558

Bower SD, Aas $\varnothing$, Arlinghaus R, Douglas Beard T, Cowx IG, Danylchuk AJ et al (2020) Knowledge gaps and management priorities for recreational fisheries in the developing world. Rev Fish Sci Aquac 00:000-000

Bradley D, Merrifield M, Miller KM, Lomonico S, Wilson JR, Gleason MG (2019) Opportunities to improve fisheries management through innovative technology and advanced data systems. Fish Fish 20(3):564-583. https://doi.org/10. 1111/faf.12361

Brooke TC, Tufts BL (2012) Fish livewell and padding system therefor. U.S. Patent Application 13/476,014, filed November 22, 2012

Brownscombe JW, Hyder K, Potts W, Wilson KL, Pope KL, Danylchuk AJ et al (2019) The future of recreational fisheries: advances in science, monitoring, management, and practice. Fish Res 211:247-255

Brownscombe JW, Danylchuk AJ, Chapman JM, Gutowsky LFG, Cooke SJ (2017) Best practices for catch-and-release recreational fisheries-angling tools and tactics. Fish Res 186:693-705

Brownscombe JW, Thiem JD, Hatry C, Cull F, Haak CR, Danylchuk AJ, Cooke SJ (2013) Recovery bags reduce post-release impairments in locomotory activity and behavior of bonefish (Albula spp.) following exposure to angling-related stressors. J Exp Mar Biol Ecol 440:207-215

Bruskotter JT, Fulton DC (2008) Minnesota anglers' fisheriesrelated value orientations and their stewardship of fish resources. Hum Dimens Wildl 13(4):207-221

Bryan H (1977) Leisure value systems and recreational specialization: the case of trout fishermen. J Leis Res 9(3): 174-187

Butcher P, Broadhurst M, Hall K, Cullis B (2012) Assessing barotrauma and release methods among angled snapper Pagrus auratus. Fish Res 127(128):49-55

Bursell JJ, Arlinghaus R (2018) Citizen science data suggest that a novel rig improves landing rate and reduces injury and handling time in recreational angling with artificial lures in Baltic pike (Esox lucius). PeerJ 6:e4744

Callaghan CT, Gawlik DE (2015) Efficacy of eBird data as an aid in conservation planning and monitoring. J Field Ornithol 86(4):298-304

Campbell LM, Cornwell ML (2008) Human dimensions of bycatch reduction technology: current assumptions and directions for future research. Endanger Species Res 5(2-3):325-334

Carpenter SR, Brock WA (2004) Spatial complexity, resilience, and policy diversity: fishing on lake-rich landscapes. Ecol Soc 9(1)
Carr WES, Derby CD (1986) Chemically stimulated feeding behaviour in marine animals. Importance of chemical mixtures and involvement of mixture interactions. J Chem Ecol 12:989-1011

Chen H, Stavinoha S, Walker M, Zhang B, Fuhlbrigge T (2014) Opportunities and challenges of robotics and automation in offshore oil and gas industry. Intell Control Autom 5:136-145

Clifford K (1992) A history of carp fishing. Sandholme Publishing, Newport, p 232

Coggins LG Jr, Catalano MJ, Allen MS, Pine WE III, Walters CJ (2007) Effects of cryptic mortality and the hidden costs of using length limits in fishery management. Fish Fish 8(3): 196-210

Colotelo AH, Cooke SJ (2011) Evaluation of common anglinginduced sources of epithelial damage for popular freshwater sport fish using fluorescein. Fish Res 109(2-3):217-224

Collier N, Doan S, Kawazoe A, Goodwin RM, Conway M, Tateno Y, Ngo QH, Dien D, Kawtrakul A, Takeuchi K, Shigematsu M, Taniguchi K (2008) BioCaster: detecting public health rumors with a Web-based text mining system. Bioinformatics 24:2940-2941

Cooke SJ, Cowx IG (2004) The role of recreational fishing in global fish crises. Bioscience 54(9):857-859

Cooke SJ, Cowx IG (2006) Contrasting recreational and commercial fishing: searching for common issues to promote unified conservation of fisheries resources and aquatic environments. Biol Conserv 128:93-108

Cooke SJ, Suski CD (2004) Are circle hooks an effective tool for conserving marine and freshwater recreational catch-andrelease fisheries? Aquat Conserv Mar Freshw Ecosyst 14(3):299-326

Cooke SJ, Suski CD (2005) Do we need species-specific guidelines for catch-and-release recreational angling to effectively conserve diverse fishery resources? Biodivers Conserv 14(5):1195-1209

Cooke SJ, Schreer JF, Wahl, DH, Philipp DP (2002) Physiological impacts of catch-and-release angling practices on largemouth bass and smallmouth bass. In American fisheries society symposium. American Fisheries Society, pp 489-512

Cooke SJ, Suski CD, Arlinghaus R, Danylchuk AJ (2013) Voluntary institutions and behaviours as alternatives to formal regulations in recreational fisheries management. Fish Fish 14(4):439-457

Cooke SJ, Wilson AD, Elvidge CK, Lennox RJ, Jepsen N, Colotelo AH, Brown RS (2016) Ten practical realities for institutional animal care and use committees when evaluating protocols dealing with fish in the field. Rev Fish Biol Fish 26(1):123-133

Cooke SJ, Twardek WM, Reid AJ, Lennox RJ, Danylchuk SC, Brownscombe JW et al (2019) Searching for responsible and sustainable recreational fisheries in the Anthropocene. J Fish Biol 94(6):845-856. https://doi.org/10.1111/jfb. 13935

Danner GR, Chacko J, Brautigam F (2009) Voluntary ingestion of soft plastic fishing lures affects brook trout growth in the laboratory. North Am J Fish Manag 29(2):352-360

Danylchuk AJ, Adams A, Cooke SJ, Suski CD (2008) An evaluation of the injury and short-term survival of bonefish 
(Albula spp.) as influenced by a mechanical lip-gripping device used by recreational anglers. Fish Res 93(1-2):248-252

Danylchuk AJ, Danylchuk SC, Kosiarski A, Cooke SJ, Huskey B (2018) Keepemwet fishing - an emerging social brand for disseminating best practices for catch-and-release in recreational fisheries. Fish Res 205:52-56

Dassow CJ, Ross AJ, Jensen OP, Sass GG, van Poorten BT, Solomon CT, Jones SE (2020) Experimental demonstration of catch hyperstability from habitat aggregation, not effort sorting, in a recreational fishery. Can J Fish Aquat Sci 77(4):762-769

Detmer TM, Broadway KJ, Parkos JJ III, Diana MJ, Wahl DH (2020) Fishing efficiency of competitive largemouth bass tournament anglers has increased since early 21 st century. Fish Manag Ecol 27(5):540-543

Devall B, Harry J (1981) Who hates whom in the great outdoors: the impact of recreational specialization and technologies of play. Leis Sci 4(4):399-418

Diggles BK (2011) Risk analysis. Aquatic animal diseases associated with domestic bait translocation. Final report prepared for the Australian Government Department of Agriculture, Fisheries and Forestry, Canberra, FRDC Project No. 2009/072. 296 pgs. https://www.frdc.com.au/ project/2009-072

Diggles BK, Ernst I, Wesche S (2020) Influence of fish attractant on the hooking location of Lutjanus carponotatus and Epinephelus quoyanus using soft and hard bodied lures. In: Ninth world recreational fishing conference, Rotterdam, 28 June-2 July 2020. (Abstract)

Ditton RB, Loomis DK, Choi S (1992) Recreation specialization: re-conceptualization from a social worlds perspective. J Leis Res 24(1):33-51

Ditton RB, Holland SM, Anderson DK (2002) Recreational fishing as tourism. Fisheries 27(3):17-24

Drumhiller KL, Johnson MW, Diamond SL, Reese Robillard MM, Stunz GW (2014) Venting or rapid recompression increase survival and improve recovery of Red Snapper with barotrauma. Mar Coast Fish 6(1):190-199

Dunmall KM, Cooke SJ, Schreer JF, McKinley RS (2001) The effect of scented lures on the hooking injury and mortality of smallmouth bass caught by novice and experienced anglers. North Am J Fish Manag 21:242-248

Dunn DC, Maxwell SM, Boustany AM, Halpin PN (2016) Dynamic ocean management increases the efficiency and efficacy of fisheries management. Proc Natl Acad Sci 113(3):668-673. https://doi.org/10.1073/pnas. 1513626113

Dunn DC, Jablonicky C, Crespo GO, McCauley DJ, Kroodsma DA, Boerder K, Gjerde KM, Halpin PN (2018) Empowering high seas governance with satellite vessel tracking data. Fish Fish 19:729-739

Dyer B (2015) The controversy of sports technology: a systematic review. SpringerPlus 4(1):524

Eigaard OR, Marchal P, Gislason H, Rijnsdorp AD (2014) Technological development and fisheries management. Rev Fish Sci Aquac 22(2):156-174. https://doi.org/10. 1080/23308249.2014.89955

Elmer LK, Kelly LA, Rivest S, Steell SC, Twardek WM, Danylchuk AJ et al (2017) Angling into the future: ten commandments for recreational fisheries science, management, and stewardship in a good Anthropocene. Environ Manag 60(2):165-175

Erisman BE, Allen LG, Claisse JT, Pondella DJ, Miller EF, Murray JH (2011) The illusion of plenty: hyperstability masks collapses in two recreational fisheries that target fish spawning aggregations. Can $J$ Fish Aquat Sci 68(10):1705-1716

European Inland Fisheries Advisory Commission (2008) FAO European inland fisheries advisory commission: EIFAC code of practice for recreational fisheries. EIFAC Occasional Paper, 42

FAO (1997) Technical guidelines for responsible fisheries. FAO, Rome

FAO (Food and Agricultural Organization of the United Nations) (2012) Technical guidelines for responsible fisheries: recreational fisheries. Food and Agriculture Organization of the United Nations, Rome, p 176

Feiner ZS, Latzka AW, Wolter MH, Eslinger LD, Hatzenbeler GR (2020) Assessing the rage against the machines: do ice anglers' electronics improve catch and harvest rates? Fisheries. 45:327-333

Field and Stream (1986) Berkley strike fish attractant formula. Field Stream 90:39-40

Fish Lure Corp (1954) Amazing new way to catch more fish. Pop Sci 164(6):7

Fisheries and Oceans Canada (2019) Fishery notice. https:// notices.dfo-mpo.gc.ca/fns-sap/index-eng.cfm?pg=view_ notice $\& D O C \_I D=220071 \& \mathrm{ID}=$ all $\&$ fbclid $=$ IwAR0k8zxz01upWeyzU53xzT6JJnxp9vqI7H5CGwaIpcJWcUuTo_ TizSK7Ts

Floreano D, Wood RJ (2015) Science, technology and the future of small autonomous drones. Nature 521:460-466

Foreman-Tran K, Schnurr K, Pardo ACR, Minda JP (2020) Should it Stay or Should it Go? Smartphone dependency. STEM Fellowsh J 5(1):19-23

Froese R, Demirel N, Coro G, Kleisner KM, Winker H (2017) Estimating fisheries reference points from catch and resilience. Fish Fish 18(3):506-526

Fujita M, Yamasaki S, Katagiri C, Oshiro I, Sano K, Kurozumi T, Sugawara H, Kunikita D, Matsuzaki H, Kano A, Okumura $T$ (2016) Advanced maritime adaptation in the western Pacific coastal region extends back to 35000-30000 years before present. Proc Natl Acad Sci 113(40):11184-11189

Garcia SM (1995) The precautionary approach to fisheries and its implications for fishery research, technology and management: an updated review. FAO Technical Paper, 350.

Gilliland ER (2003) Livewell operating procedures to reduce mortality of black bass during summer tournaments. In: Philipp DP, Ridgway MS (eds) Black bass: ecology conservation and management. American Fisheries Society Symposium, vol 31. American Fisheries Society, Bethesda, pp 477-487

Glass CW, Walsh SJ, van Marlen B, Amaratunga T (2007) Fishing technology in the 21st century: integrating fishing and ecosystem conservation. ICES J Mar Sci 64(8):1499-1616

Gould A, Grace BS (2009) Injuries to barramundi Lates calcarifer resulting from lip-gripping devices in the laboratory. North Am J Fish Manag 29(5):1418-1424 
Graham AL, Cooke SJ (2008) The effects of noise disturbance from various recreational boating activities common to inland waters on the cardiac physiology of a freshwater fish, the largemouth bass (Micropterus salmoides). Aquat Conserv Mar Freshw Ecosyst 18(7):1315-1324

Granek EF, Madin EM, Brown MA, Figueira W, Cameron DS, Hogan Z et al (2008) Engaging recreational fishers in management and conservation: global case studies. Conserv Biol 22(5):1125-1134

Gutowsky LFG, Sullivan BG, Wilson ADM, Cooke SJ (2017) Synergistic and interactive effects of angler behaviour, gear type, and fish behaviour on hooking depth in passively angled fish. Fish Res 186:612-618

Hamel S, Killengreen ST, Henden JA, Eide NE, Roed-Eriksen L, Ims RA, Yoccoz NG (2013) Towards good practice guidance in using camera-traps in ecology: influence of sampling design on validity of ecological inferences. Methods Ecol Evol 4(2):105-113

Hara TJ (1994) The diversity of chemical stimulation in fish olfaction and gustation. Rev Fish Biol Fish 4:1-35

Harley SJ, Myers RA, Dunn A (2001) Is catch-per-unit-effort proportional to abundance? Can J Fish Aquat Sci 58(9):1760-1772

Harmon LK, Gleason M (2009) Underwater explorers: using remotely operated vehicles (ROVs) to engage youth with underwater environments. Child Youth Environ 19:125-143

Harrison QP (2004) Fish hook removal apparatus. U.S. Patent No. 6,705,042. U.S. Patent and Trademark Office, Washington, DC

Hartill BW, Taylor SM, Keller K, Weltersbach MS (2020) Digital camera monitoring of recreational fishing effort: applications and challenges. Fish Fish 21(1):204-215. https://doi.org/10.1111/faf.12413

Hilborn R, Maguire JJ, Parma AM, Rosenberg AA (2001) The precautionary approach and risk management: can they increase the probability of successes in fishery management? Can J Fish Aquat Sci 58(1):99-107

Holder PE, Jeanson AL, Lennox RJ, Brownscombe JW, Arlinghaus R, Danylchuk AJ et al (2020) Preparing for a changing future in recreational fisheries: 100 research questions for global consideration emerging from a horizon scan. Rev Fish Biol Fish 30:137-151

Hopkins SP (2017) Antimicrobial containing fish hook and method of using and manufacturing same. U.S. Patent $9,572,329$

Horne JK (2000) Acoustic approaches to remote species identification: a review. Fish Oceanogr 9(4):356-371

Hummel RL, Foster GS (1986) A sporting chance: relationships between technological change and concepts of fair play in fishing. J Leis Res 18(1):40-52

Hunt LM, Arlinghaus R, Lester N, Kushneriuk R (2011) The effects of regional angling effort, angler behavior, and harvesting efficiency on landscape patterns of overfishing. Ecol Appl 21(7):2555-2575

Jarić I, Correia RA, Brook BW, Buettel JC, Courchamp F, Di Minin E, Firth JA, Gaston KJ, Jepson P, Kalinkat G, Ladle $\mathrm{R}$ (2020) iEcology: harnessing large online resources to generate ecological insights. Trends Ecol Evol 00:000-000

Jennings S, Stentiford GD, Leocadio AM, Jeffery KR, Metcalfe JD, Katsiadaki I et al (2016) Aquatic food security: insights into challenges and solutions from an analysis of interactions between fisheries, aquaculture, food safety, human health, fish and human welfare, economy and environment. Fish Fish 17(4):893-938. https://doi.org/10.1111/faf. 12152

Jiorle RP, Ahrens RNM, Allen MS (2016) Assessing the utility of a smartphone app for recreational fishery catch data. Fisheries 41(12):758-766. https://doi.org/10.1080/ 03632415.2016.1249709

Johnsen JP (2005) The evolution of the "harvest machinery": why capture capacity has continued to expand in Norwegian fisheries. Mar Policy 29(6):481-493

Johnston FD, Beardmore B, Arlinghaus R (2015) Optimal management of recreational fisheries in the presence of hooking mortality and noncompliance-predictions from a bioeconomic model incorporating a mechanistic model of angler behavior. Can J Fish Aquat Sci 72:37-53

Jones KA (1989) The palatability of amino acids and related compounds to rainbow trout, Salmo gairdneri Richardson. J Fish Biol 34:149-160

Jones KA (1990) Chemical requirements of feeding in rainbow trout, Oncorhynchus mykiss (Walbaum); palatability studies on amino acids, amides, amines, alcohols, aldehydes, saccharides, and other compounds. J Fish Biol 37:413-423

Jones CM, Pollock KH (2012) Recreational angler survey methods: estimation of effort, harvest, and released catch. In: Zale AV, Parrish DL, Sutton TM (eds) Fisheries techniques. American Fisheries Society, Bethesda, pp 883-919

Jorgensen C, Enberg K, Dunlop ES et al (2007) Managing evolving fish stocks. Science 318:1247-1248

Joubert BA, Sullivan MG, Kissinger BC, Meinke AT (2020) Can smartphones kill Trout? Mortality of memorable-sized Bull Trout (Salvelinus confluentus) after photo-releases. Fish Res 223:105458

Kain MP, Bolker BM (2019) Predicting West Nile virus transmission in North American bird communities using phylogenetic mixed effects models and eBird citizen science data. Parasites Vectors 12(1):395

Kalkbrenner J, McCampbell A (2011) The advent of smartphones: a study on the effect of handheld electronics on personal and professional productivity. J Appl Global Res 4(8)

Kasumyan AO (2019) The taste system in fish and the effects of environmental variables. J Fish Biol 95:155-178

Kasumyan A, Doving KB (2003) Taste preferences in fish. Fish Fish 4:289-347

Keramidas I, Dimarchopoulou D, Pardalou A, Tsikliras AC (2018) Estimating recreational fishing fleet using satellite data in the Aegean and Ionian Seas (Mediterranean Sea). Fish Res 208:1-6

Koeck B, Závorka L, Aldvén D, Näslund J, Arlinghaus R, Thörnqvist PO, Winberg S, Björnsson BT, Johnsson JI (2019) Angling selects against active and stress-resilient phenotypes in rainbow trout. Can J Fish Aquat Sci 76(2):320-333

Koeck B, Lovén Wallerius M, Arlinghaus R, Johnsson JI (2020) Behavioural adjustment of fish to temporal variation in fishing pressure affects catchability: an experiment with angled trout. Can J Fish Aquat Sci 77(1):188-193 
Keretz KR, Dinken CP, Allen PJ, Colvin ME, Schramm HL Jr (2018) The effect of water temperature, angling time, and dissolved oxygen on the survival of largemouth bass subjected to simulated angling and tournament handling procedures. North Am J Fish Manag 38(3):606-622

Lee JM (2017) Dual barb fish hook. U.S. Patent Application $14 / 829,609$

Lee K, Sener IN (2019) Understanding potential exposure of bicyclists on roadways to traffic-related air pollution: findings from El Paso, Texas, Using Strava Metro Data. Int J Environ Res Public Health 16(3):371

Lennox RJ, Alós J, Arlinghaus R, Horodysky A, Klefoth T, Monk CT, Cooke SJ (2017) What makes fish vulnerable to capture by hooks? A conceptual framework and a review of key determinants. Fish Fish 18(5):986-1010

Lester NP, Marshall TR, Armstrong K, Dunlop WI, Ritchie B (2003) A broad-scale approach to management of Ontario's recreational fisheries. North Am J Fish Manag 23(4):1312-1328

Lewin W-C, Weltersbach MS, Ferter K, Hyder K, Mugerza E, Prellezo R et al (2019) Potential environmental impacts of recreational fishing on marine fish stocks and ecosystems. Rev Fish Sci Aquac 27(3):287-330

Lindenmayer D, Scheele B (2017) Do not publish. Science 356(6340):800-801

Little AS, Needle CL, Hilborn R, Holland DS, Marshall CT (2015) Real-time spatial management approaches to reduce bycatch and discards: experiences from Europe and the United States. Fish Fish 16(4):576-602. https://doi.org/ 10.1111/faf.12080

Liu B, Stokes L, Topping T, Stunz G (2017) Estimation of a total from a population of unknown size and application to estimating recreational red snapper catch in Texas. J Surv Stat Methodol 5(3):350-371

Loeb HA (1960) Reactions of aquarium carp to food and flavours. New York Fish Game J 7:61-71

Lorimer CA, Ray CK (FLUOROHOOK LLC) (2016) Fluorocarbon fishing hook and methods of manufacture. U.S. Patent Application 14/947,796

Ludwig HR, Leitch JA (1996) Interbasin transfer of aquatic biota via anglers' bait buckets. Fisheries 21:14-18

Mackay M, Jennings S, van Putten EI, Sibly H, Yamazaki S (2018) When push comes to shove in recreational fishing compliance, think 'nudge.' Mar Policy 95:256-266. https://doi.org/10.1016/j.marpol.2018.05.026

Mackay M, Yamazaki S, Jennings S, Sibly H, van Putten IE, Emery TJ (2019) The influence of nudges on compliance behaviour in recreational fisheries: a laboratory experiment. ICES J Mar Sci. https://doi.org/10.1093/icesjms/ fsz020

Mackie AM (1982) Identification of the gustatory feeding stimulants. In: Hara TJ (ed) Chemoreception in fishes. Elsevier, Amsterdam, pp 275-291

Macreadie PI, McLean DL, Thomson PG, Partridge JC, Jones DO, Gates AR et al (2018) Eyes in the sea: unlocking the mysteries of the ocean using industrial, remotely operated vehicles (ROVs). Sci Total Environ 634:1077-1091

Maggs JQ, Mann BQ, Potts WM, Dunlop SW (2016) Traditional management strategies fail to arrest a decline in the catchper-unit-effort of an iconic marine recreational fishery species with evidence of hyperstability. Fish Manag Ecol 23(3-4):187-199

Mangi SC, Dolder PJ, Catchpole TL, Rodmell D, de Rozarieux N (2015) Approaches to fully documented fisheries: practical issues and stakeholder perceptions. Fish Fish 16(3):426-452. https://doi.org/10.1111/faf.12065

Marchal P, Andersen B, Caillart B, Eigaard O, Guyader O, Hovgaard $\mathrm{H}$ et al (2006) Impact of technological creep on fishing effort and fishing mortality, for a selection of European fleets. ICES J Mar Sci 64(1):192-209

Markowitz EM, Nisbet MC, Danylchuk AJ, Engelbourg SI (2017) What's that buzzing noise? Public opinion on the use of drones for conservation science. Bioscience 67:382-385

Martin DR, Chizinski CJ, Eskridge KM, Pope KL (2014) Using posts to an online social network to assess fishing effort. Fish Res 157:24-27. https://doi.org/10.1016/j.fishres.2014. 03.013

Maxwell SM, Hazen EL, Lewison RL, Dunn DC, Bailey H, Bograd SJ et al (2015) Dynamic ocean management: defining and conceptualizing real-time management of the ocean. Mar Policy 58:42-50. https://doi.org/10.1016/j. marpol.2015.03.014

Mazumdar S, Ceccaroni L, Piera J, Hölker F, Berre A, Arlinghaus R, Bowser A (2018) Citizen science technologies and new opportunities for participation. UCL Press, London

McFann CB, McFann BL (2010) One-piece fish hook disgorger and method of use. U.S. Patent Application 12/387,894, filed November 11, 2010

Menzebach F, Göllner E (2005) Weidgerechte Angelfischerei: Ethische Betrachtung einer Passion. Mächler Media; 3., rev. u. erw. Neuaufl. Edition. Pp 144.

Meronek TG, Copes FA, Coble DW (1995) A summary of bait regulations in the north central United States. Fisheries 20(11):16-23

Merwin J (2007) The (mad) science of lure design. Field Stream 111:62-65

Méry S, Charpentier V, Beech M (2008) First evidence of shell fish-hook technology in the Gulf. Arab Archaeol Epigr 19(1):15-21

Miah A (2000a) "New balls please": tennis, technology, and the changing game. In: Haake SA, Coe AO (eds) Tennis, science, and technology. Blackwell Science, London, pp 285-292

Miah A (2000b) Climbing upwards of climbing backwards? The technological metamorphoses of climbing and mountaineering. In: Messenger N, Patterson W, Brook D (eds) The science of climbing and mountaineering [CD-ROM Chapter 27]. Human Kinetics, London

Monk CT, Arlinghaus R (2017) Encountering a bait is necessary but insufficient to explain individual variability in vulnerability to angling in two freshwater benthivorous fish in the wild. PLoS ONE 12(3):e01739899

Monk CT, Arlinghaus R (2018) Eurasian perch, Perca fluviatilis, spatial behaviour determines vulnerability independent of angler skill in a whole-lake reality mining experiment. Can J Fish Aquat Sci 75:417-428

Monkman GG, Kaiser M, Hyder K (2018a) The ethics of using social media in fisheries research. Rev Fish Sci Aquac 26(2):235-242. https://doi.org/10.1080/23308249.2017. 1389854 
Monkman GG, Kaiser MJ, Hyder K (2018b) Text and data mining of social media to map wildlife recreation activity. Biol Cons 228:89-99. https://doi.org/10.1016/j.biocon. 2018.10.010

Moreno G, Dagorn L, Capello M, Lopez J, Filmalter J, Forget F et al (2016) Fish aggregating devices (FADs) as scientific platforms. Fish Res 178:122-129

Muller RG, Trotter AA, Stevens PW (2013) The 2013 stock assessment update of common snook, Centropomus undecimalis. Florida Fish and Wildlife Conservation Commission, Fish and Wildlife Research Institute Report 2015-004, $191 \mathrm{pp}$

Murchie KJ, Danylchuk SE, Pullen CE, Brooks E, Shultz AD, Suski CD, Danylchuk AJ, Cooke SJ (2009) Strategies for the capture and transport of bonefish, Albula vulpes, from tidal creeks to a marine research laboratory for long-term holding. Aquac Res 40(13):1538-1550

Mussweiler T (2003) Comparison processes in social judgment: mechanisms and consequences. Psychol Rev 110(3):472-489

Myers RA, Barrowman NJ, Hutchings JA, Rosenberg AA (1995) Population dynamics of exploited fish stocks at low population levels. Science 269(5227):1106-1108

Norris C, McCahill M (2006) CCTV: beyond penal modernism? Br J Criminol 46(1):97-118

Obar JA, Wildman S (2015) Social media definition and the governance challenge: an introduction to the special issue. Telecommu Policy 39(9):745-750

O'Connor S, Ono R, Clarkson C (2011) Pelagic fishing at 42,000 years before the present and the maritime skills of modern humans. Science 334(6059):1117-1121

Ostrand KG, Siepker MJ, Wahl DH (2011) Effectiveness of livewell additives on largemouth bass survival. J Fish Wildl Manag 2(1):22-28

Palomares ML, Pauly D (2019) On the creeping increase of vessels' fishing power. Ecol Soc 24(3):31-38

Papenfuss JT, Phelps N, Fulton D, Venturelli P (2015) Smartphones reveal angler behavior: a case study of a popular mobile fishing application in Alberta, Canada. Fisheries 40(7):318-327. https://doi.org/10.1080/03632415.2015. 1049693

Pelletier C, Hanson KC, Cooke SJ (2007) Do catch-and-release guidelines from state and provincial fisheries agencies in North America conform to scientifically based best practices? Environ Manag 39(6):760-773

Perritt HH Jr, Sprague EO (2017) Domesticating drones: the technology, law, and economics of unmanned aircraft. Routledge, New York, p 416

Pimm SL, Alibhai S, Bergl R, Dehgan A, Giri C, Jewell Z, Joppa L, Kays R, Loarie S (2015) Emerging technologies to conserve biodiversity. Trends Ecol Evol 30:685-696

Polgreen PM, Chen Y, Pennock DM, Nelson FD (2008) Using internet searches for influenza surveillance. Clin Infect Dis 47(11):1443-1448

Pope KL, Wilde GR, Bauer DL (2005) Maximum size of fish caught with standard gears and recreational angling. Fish Res 76(1):117-122

Post JR, Parkinson EA (2012) Temporal and spatial patterns of angler effort across lake districts and policy options to sustain recreational fisheries. Can J Fish Aquat Sci 69(2):321-329
Post JR, Sullivan M, Cox S, Lester NP, Walters CJ, Parkinson EA et al (2002) Canada's recreational fisheries: the invisible collapse? Fisheries 27(1):6-17

Post JR, Persson L, Parkinson EV, Kooten TV (2008) Angler numerical response across landscapes and the collapse of freshwater fisheries. Ecol Appl 18(4):1038-1049

Probst WN (2019) How emerging data technologies can increase trust and transparency in fisheries. ICES J Mar Sci. https://doi.org/10.1093/icesjms/fsz036

Punt AE, Smith AD (2001) The gospel of maximum sustainable yield in fisheries management: birth, crucifixion and. Conserv Exploited Species 6:41

Raby GD, Donaldson MR, Hinch SG, Clark TD, Eliason EJ, Jeffries KM, Cook KV, Teffer A, Bass AL, Miller KM, Patterson DA (2015) Fishing for effective conservation: context and biotic variation are keys to understanding the survival of Pacific salmon after catch-and-release. Integr Comp Biol 55(4):554-576

Radomski PJ, Grant GC, Jacobson PC, Cook MF (2001) Visions for recreational fishing regulations. Fisheries 26(5):7-18

Raison T, Nagrodski A, Suski CD, Cooke SJ (2014) Exploring the potential effects of lost or discarded soft plastic fishing lures on fish and the environment. Water Air Soil Pollut 225:1869

Rapp T, Cooke SJ, Arlinghaus R (2008) Exploitation of specialised fisheries resources: the importance of hook size in recreational angling for large common carp (Cyprinus carpio L.). Fish Res 94:79-83

Rapp T, Hallermann J, Cooke SJ, Hetz SK, Wuertz S, Arlinghaus R (2014) Consequences of air exposure on the physiology and behavior of caught-and-released common carp in the laboratory and under natural conditions. North Am J Fish Manag 34(2):232-246

Richardson EA, Kaiser MJ, Edwards-Jones G, Ramsay K (2006) Trends in sea anglers' catches of trophy fish in relation to stock size. Fish Res 82:253-262. https://doi.org/10.1016/j. fishres.2006.05.014

Rintala J (1995) Sport and technology: human questions in a world of machines. J Sport Soc Issues 19(1):62-75

Roco MC, Bainbridge WS (2013) The new world of discovery, invention, and innovation: convergence of knowledge, technology, and society. J Nanopart Res 15(9):1946

Rogers EM (1962) Diffusion of innovations. Free Press, New York

Rogers BL, Lowe CG, Fernandez-Juricic E, Frank LR (2008) Utilizing magnetic resonance imaging (MRI) to assess the effects of angling-induced barotrauma on rockfish (Sebastes). Can J Fish Aquat Sci 65(7):1245-1249

Sanft EJ, Porreca AP, Parkos JJ, Detmer TM, Wahl DH (2018) Effects of ingestion of soft plastic fishing lures on largemouth bass. North Am J Fish Manag 38:718-724

Sauls B, Ayala O (2012) Circle hook requirements in the Gulf of Mexico: application in recreational fisheries and effectiveness for conservation of reef fishes. Bull Mar Sci 88(3):667-679

Savvas K (2009) Making sense of scents. Fishing World, pp 40-44

Sbragaglia V, Correia RA, Coco S, Arlinghaus R (2020) Data mining on YouTube reveals fisher group-specific harvesting patterns and social engagement in recreational anglers 
and spearfishers. ICES J Mar Sci 77(6):2234-2244. https:// doi.org/10.1093/icesjms/fsz100

Scherrer K, Galbraith E (2020) Regulation strength and technology creep play key roles in global long-term projections of wild capture fisheries. ICES J Mar Sci 77(7-8):2518-2528

Schill DJ, Scarpella RL (1997) Barbed hook restrictions in catch-and-release trout fisheries: a social issue. North Am J Fish Manag 17:873-881

Schisler G, Bergersen EP (1996) Postrelease hooking mortality of rainbow trout caught on scented artificial baits. North Am J Fish Manag 16:570-578

Schramm HL, Arey SD, Miko DA, Gerard PD (1998) Angler perceptions of fishing success and the effect of on-site catch rate information. Hum Dimens of Wildl 3(3):1-10

Schultz K (2004) Better than bait? Why biodegradable lures may be the future of fishing. Field Stream 108:25-26

Scott-Orr H, Jones JB, Bhatia N (2017). Uncooked prawn imports: effectiveness of biosecurity controls. Australian Government Inspector-General of Biosecurity Review report No. 2017-18/01. 180 pgs. https:/www.igb.gov.au/ uncooked-prawn-imports-effectiveness-biosecuritycontrols

Seekell DA (2011) Recreational freshwater angler success is not significantly different from a random catch model. North Am J Fish Manag 31(2):203-208

Seekell DA, Brosseau CJ, Cline TJ, Winchcombe RJ, Zinn LJ (2011) Long-term changes in recreational catch inequality in a trout stream. North Am J Fish Manag 31(6):1100-1105

Shiffman DS, Macdonald C, Ganz HY, Hammerschlag N (2017) Fishing practices and representations of shark conservation issues among users of a land-based shark angling online forum. Fish Res 196:13-26

Struthers DP, Danylchuk AJ, Wilson AD, Cooke SJ (2015) Action cameras: bringing aquatic and fisheries research into view. Fisheries 40(10):502-512

Stunz GW, Johnson MJ, Yoskowitz D, Robillard M, Wetz J (2014) iSnapper: Design, testing, and analysis of an iPhone-based application as an electronic logbook in the for-hire gulf of Mexico red snapper fishery. National Oceanic and Atmospheric Administration. Final Report NA10NMF4540111. $64 \mathrm{pp}$

Sun Y, Du Y, Wang Y, Zhuang L (2017) Examining associations of environmental characteristics with recreational cycling behaviour by street-level Strava data. Int J Environ Res Public Health 14(6):644

Suski CD, Killen SS, Kieffer JD, Tufts BL (2006) The influence of environmental temperature and oxygen concentration on the recovery of largemouth bass from exercise: implications for live-release angling tournaments. J Fish Biol 68(1):120-136

Sutter DA, Suski CD, Philipp DP, Klefoth T, Wahl DH, Kersten $P$ et al (2012) Recreational fishing selectively captures individuals with the highest fitness potential. Proc Natl Acad Sci 109(51):20960-20965

Talmage PJ, Staples DF (2011) Mortality of Walleyes angled from the deep waters of Rainy Lake, Minnesota. North Am J Fish Manag 31(5):826-831

Thomas SN, Edappazham G, Meenakumari B, Ashraf PM (2007) Fishing hooks: a review. Fish Technol 44:1-16
Tidd A, Brouwer S, Pilling G (2017) Shooting fish in a barrel? Assessing fisher-driven changes in catchability within tropical tuna purse seine fleets. Fish Fish 18(5):808-820

Tobin CD (2015) Lights, cameras, drones! Litigation 42:1-3

Toonen HM, Bush SR (2018) The digital frontiers of fisheries governance: fish attraction devices, drones and satellites. J Environ Policy Plan. https://doi.org/10.1080/1523908X. 2018.1461084

Trahan AT, Chhor AD, Lawrence MJ, Brownscombe JW, Glassman DM, Reid CH, Abrams AE, Danylchuk AJ, Cooke SJ (2020) Do carbonated beverages reduce bleeding from gill injuries in angled Northern Pike? North Am J Fish Manag

Twardek WM, Lennox RJ, Lawrence MJ, Logan JM, Szekeres P, Cooke SJ, Tremblay K, Morgan GE, Danylchuk AJ (2018) The postrelease survival of Walleyes following iceangling on Lake Nipissing, Ontario. North Am J Fish Manag 38(1):159-169

Venturelli PA, Hyder K, Skov C (2017) Angler apps as a source of recreational fisheries data: opportunities, challenges and proposed standards. Fish Fish 18(3):578-595

Waluda CM, Trathan PN, Elvidge CD, Hobson VR, Rodhouse PG (2011) Throwing light on straddling stocks of Illex argentinus: assessing fishing intensity with satellite imagery. Can J Fish Aquat Sci 59(4):592-596

Walton I (2019). The complete angler 1653. Litres

Wang F (2016) Creation method of a fishhook with attractant. U.S. Patent 9,491,936

Wang SG, Wang RZ (2005) Recent developments of refrigeration technology in fishing vessels. Renew Energy 30(4):589-600

Ward HG, Askey PJ, Post JR (2013) A mechanistic understanding of hyperstability in catch per unit effort and density-dependent catchability in a multistock recreational fishery. Can J Fish Aquat Sci 70(10):1542-1550

Ward AF, Duke K, Gneezy A, Bos MW (2017) Brain drain: the mere presence of one's own smartphone reduces available cognitive capacity. J Assoc Consumer Res 2(2):140-154

Widmer L, Heule E, Colombo M, Rueegg A, Indermaur A, Ronco F, Salzburger W (2019) Point-combination transect (PCT): incorporation of small underwater cameras to study fish communities. Methods Ecol Evol 10(6):891-901

Wilde GR (2009) Does venting promote survival of released fish? Fisheries 34(1):20-28

Wils A (1998) End-use or extraction efficiency in natural resource utilization: which is better? Syst Dyn Rev 14(2-3): 163-188

Wilson DC, Nielsen JR, Degnbol P (eds) (2003) The fisheries co-management experience: accomplishments, challenges and prospects, vol 26. Springer, Cham.

Winter LA (2017) Multiple barb fish hook. U.S. Patent $9,565,842$

Yared R, Mallat HK, Abdulrazak B (2015) Ambient technology to support elderly people in outdoor risk situations. In: International conference on information and communication technologies for ageing well and e-health. Springer, Cham, pp 35-56

Yepez R, Guevara N (2017) Barbless safety fishhook. U.S. Patent 9,743,648

Yoerger DR, Bradley AM, Jakuba M, German CR, Shank T, Tivey M (2007) Autonomous and remotely operated 
vehicle technology for hydrothermal vent discovery, exploration, and sampling. Oceanography 20(1):152-161 Zacharie M, Kyuhei H (2017) Preliminary assessment for inshore fishing UAV (ISFUAV). J Adv Control Autom Robotics 3:113-119
Publisher's Note Springer Nature remains neutral with regard to jurisdictional claims in published maps and institutional affiliations. 